Article

\title{
Analyzing the Barriers to Reverse Logistics (RL) Implementation: A Hybrid Model Based on IF-DEMATEL-EDAS
}

\author{
Chukwuebuka M. U-Dominic ${ }^{1}$ (D) , Ifeyinwa Juliet Orji ${ }^{2, *}$ and Modestus Okwu ${ }^{3}$ \\ 1 Department of Industrial and Production Engineering, Faculty of Engineering, Nnamdi Azikiwe University, \\ Awka 5025, Nigeria; bukkyudom@yahoo.com \\ 2 Research Center for Smarter Supply Chain, School of Business, Soochow University, Suzhou 215006, China \\ 3 Department of Mechanical Engineering, Federal University of Petroleum Resources, Uvwie 330102, Nigeria; \\ mechanicalmodestus@yahoo.com \\ * Correspondence: ifyorji09@yahoo.com
}

Citation: U-Dominic, C.M.; Orji, I.J.; Okwu, M. Analyzing the Barriers to Reverse Logistics (RL)

Implementation: A Hybrid Model Based on IF-DEMATEL-EDAS.

Sustainability 2021, 13, 10876.

https://doi.org/10.3390/

su131910876

Academic Editor: António Abreu

Received: 28 August 2021

Accepted: 21 September 2021

Published: 30 September 2021

Publisher's Note: MDPI stays neutral with regard to jurisdictional claims in published maps and institutional affiliations.

Copyright: (c) 2021 by the authors. Licensee MDPI, Basel, Switzerland. This article is an open access article distributed under the terms and conditions of the Creative Commons Attribution (CC BY) license (https:/ / creativecommons.org/licenses/by/ $4.0 /)$.

\begin{abstract}
Recently, manufacturing companies aspire to implement reverse logistics in response to stakeholders' requirements to reduce negative environmental consequences, improve organizational sustainable performance and ultimately increase competitive advantage. However, implementing reverse logistics can be impeded by a criteria framework, and necessitates the careful analysis of how such criteria interact with each other in the presence of uncertainty. Thus, in this study, we propose an integrated multi- criteria decision-making (MCDM) methodology that leverages the Decision Making Trial and Evaluation Laboratory (DEMATEL) under Intuitionistic Fuzzy (IF) environment and Evaluation Based on Distance to Average Solution (EDAS). Within the proposed methodology, firstly, the IF-DEMATEL is applied to obtain the interrelationships between the criteria/barriers and then, the EDAS method is applied to prioritize the criteria based on the appraisal scores evaluation. An application case within the Nigerian manufacturing sector was utilized to illustrate the viability of the proposed methodology. The study results indicate that the highly prioritized barriers to implementing reverse logistics within the Nigerian manufacturing sector include low product quality, risk of storing hazardous materials and low technical expertise. Consequently, this study makes a profound contribution to the theory and practice of reverse logistics by presenting an integrated MCDM methodology that can effectively address the criticality of barriers in the way of reverse logistics progression in a complex and uncertain scenario.
\end{abstract}

Keywords: reverse logistics; multi-criteria decision-making (MCDM); barriers; IF-DEMATEL; EDAS

\section{Introduction}

Reverse logistics (RL) is considered a vital element of the circularity concept- a regenerative or restorative perspective of the industrial economy [1,2] and is among the fastest-growing supply chain management research [3]. Unlike traditional linear logistics that start from the producer to the end-customer, reverse logistics entails the reverse flow that determines a closed-loop supply chain in combination with linear logistics. In fact, a process in which a producer systematically takes in previously transported goods from the consumers for subsequent remanufacturing, reuse, recycling, or disposal is what defines reverse logistics [4]. Indeed, RL refers to the movement of goods upstream, from their point of consumption to the initiation point to add more value or properly dispose of products and as such has become popular among retailers and manufacturers given its potential to increases customer satisfaction and brand loyalty. It increases the public perception of the organization's green preference, improves proper waste disposal alternatives, reduces carbon footprints and guarantees efficient value recovering processes from used assets. Clearly, the fast-changing technology and demand of consumers for advanced and userfriendly products results in new products appearing in the market day to day, thereby 
giving rise to a high number of disposable products [5], and consequently making reverse logistics a strategic option. Since there are many disposable products that are not used to the end of the lifespan, RL treats these products as valuable industrial inputs rather than being disposed of in the form of waste [6]. The reuse of discarded items can enable firms to increase competitive advantage by improving resource efficiency, minimize costs, improve brand image and drastically reduce negative environmental consequences $[5,6]$.

In this context, RL has become one of the key competencies in modern supply chains [7] and can no longer be treated as an afterthought activity [5]. As such, organizations have started considering recycled materials as material alternatives in their production cycles and have also sought a sustainable disposal approach for products that cannot be recycled or reused. A number of reasons/factors, such as material scarcity, environmental legislation and social cognizance of clean production have necessitated firms to consider RL adoption [8]. Indeed, RL is regarded as a great enabler for sustainable production and resource circulation [9]; moreover, the recent interruptions to the global supply chains by the COVID-19 pandemic are forcing businesses to adopt RL practices to maintain market resilience [10]. Notably, the COVID-19 pandemic had far-reaching consequences beyond the primary health threat [11]. The border restrictions and Chinese sanctions have led to untold material scarcity and price inflation. In developed countries, sustainability and the preservation of natural sources is getting more important in society at large [12]. Many countries in Europe have promulgated reforms forced by legislation, through the Extended Producer Responsibility (EPR) policy to properly dispose or recycle their used products $[9,13]$. World acclaimed bodies, such as the European's waste electronics and electrical equipment (WEEE), mandate electrical and electronics producers to finance the collection, recycling, recovery and treatment of all WEEE within the EU, and the U.S. to reduce the effect of electrical and electronics goods on the environment by increasing re-use and recycling.

However, the research on the implementation of RL in developing countries is still in the nascent stage and presents huge opportunities for further exploration and theorization and of course full utilization [14-16]. Particularly, in Nigeria, most manufacturing firms lack a rudimentary understanding of how to integrate RL strategies in their product designs [16]. Presently, a huge amount of waste is generated in Nigeria manufacturing firms, considering the country's huge population strength and most of these wastes end up in landfills due to inefficient reuse alternatives and a number of deficiencies. As such, an efficient reverse logistics system is needed in the Nigerian manufacturing sector, to capture value in waste disposal systems, and this necessitates providing insights on the barriers to implementing such a system [17]. Past published studies exist in the extant literature on the barriers to implementing reverse logistics [18-21], yet there is a dearth of research that provides evidence on such a topic in the Nigerian manufacturing context, even as such barriers are bound to vary in terms of severity in different industrial contexts [22]. Reasons for why organizations embark on RL are myriad considering environmental, economic and social perspectives. There have been a number of recognized professional bodies within the manufacturer's tenets saddled with the responsibilities to approve practices in line with the green design initiative campaigns and promotions. Associated professional schemes in Nigeria like the Mandatory Conformity Assessment program (MANCAP) instituted by the Standard Organization of Nigeria (SON) and International Standard Organization (ISO-9000) are instituted to enhance the country's economic and industrial development while encouraging the respect of equal market conditions [23].

Amongst the certification procedure is the establishment of statutory production benchmarks among manufacturers of non-biodegradable materials for environmental safety. All locally manufactured products sold or exported from Nigeria must conform to the minimum Nigerian industrial standard (NIS) and approved Code of Practice. However, it is worrisome that the subjects of RL have not been well explored in practice to be a strategic sustainable conveyor among many manufacturers battling with incessant supply chain disruptions. Many manufacturers in Nigeria still focus on the sales of products to the final consumer without taking cognizance of any form of RL option. The research paper 
provides an analysis of the current state of RL implementation in Nigeria and identifies priority issues for the manufacturing executives, civil society, national government and green researchers. Therefore, the main motivation of this article is to provide answers to the enlisted research questions:

1. What are the key implementation factors that interfere with wider RL adoption among manufacturers in the Nigerian manufacturing sectors?

2. Why are there still divergent opinions among manufacturers on the reuse of used materials in the production line even with the heightened level of supply chain disruptions?

3. Why are there still a high volume of hazardous wastes, non-biodegradables in landfills, erosion dumpsites in this dispensation of circular designs and global green policy initiatives and promotions?

Moreover, analyzing the severity of the barriers to implementing reverse logistics is considered as a kind of multi-criteria decision-making (MCDM) problem since it involves more than one criterion and often with more than one conflicting objective to be considered collectively to reach the most plausible decision [23]. Consequently, MCDM methods are deemed to be reliable decision support models to effectively handle the complexities that are inherent in the multi-criteria structure of the barrier analysis of reverse logistics. Specifically, this study proposed a decision support model based on Intuitionistic Fuzzy sets, notable for accounting for not just the ambiguity of the decision makers' judgment but its lack of precision and inexact nature and as such is more preferred than standard fuzzy sets $[23,24]$. Contrary to previously published studies in reverse logistics literature, this study pioneers the synergistic application of Intuitionistic Fuzzy Decision Making Trial and Evaluation Laboratory (IF-DEMATEL) and Evaluation Based on Distance to Average Solution (EDAS) in the analysis of the barriers to implementing reverse logistics in the Nigerian manufacturing sector. The remainder of this paper is structured as follows: the review of literature on reverse logistics, MCDM methods and the barriers to implementing reverse logistics are presented in Section 2. Section 3 provides a detailed presentation of the research methodology comprising of the IF-DEMATEL and EDAS in addition to the data collection process with regards to the application case- the Nigerian manufacturing sector. The results of the analysis coupled with the discussion on the results and research implications are presented in Section 4. Section 5 details the summary of the study in addition to the study limitations and future research directions.

\section{Literature Review}

This section presents a literature review on RL implementation barriers and recent RL studies conducted in Africa.

\subsection{Literature Review on Reverse Logistics Barriers}

A comprehensive understanding of RL barriers allows manufacturing companies to prepare a priority list of actions for better implementation of the RL system [22]. Despite this, numerous barriers to RL implementations are abound in Africa [25], and there is a lack of generalized conclusions regarding the obstacles to RL in developing countries. A lot of studies have been conducted recently on RL barriers using various approaches. For example, Sari et al. [25], studied the interactions among the identified RL implementation barriers in a car battery industry in Indonesia using interpretative structural modeling. The findings from the study strongly linked financial constraint as the root barrier. Further results from MICMAC analysis identified barriers with strong driving powers as lack of awareness about RL practice, company policies, lack of information systems and technology, financial constraints, lack of commitment by top management and lack of strategic planning. Waqas et al. [22], conducted a systematic literature review on RL implementation barriers to explain RL adoption's influence on a firm's performance. Data were collected from employees in the manufacturing companies and relevant government institutes and analyzed using the structural equation modeling technique. Among the results, findings suggest that these barrier categories: financial, infrastructure \& technology, and knowledge 
\& experience-based barriers are the critical barriers that negatively impact the adoption of RL practices. Badenhorst [26], identified operational barriers to efficient RL performance employing a theoretical framework. The researcher also suggested practices that would aid in overcoming the identified barriers. Among the suggested mitigation strategies from the study is the use of a web-based approach, the use of return software, and state-of-the-art technology in RL information management systems and technology.

Vieira et al. [27], identified and analyzed the RL barriers in e-waste in the Brazilian context. The study was carried out in stages, first with a systematic literature review process to identify the main barriers. In the second phase, a Multi-criteria Decision Aid approach (MCDA) of Composition of Probabilistic Preferences (CPP) was applied to prioritize and classify the identified barriers into internal and external barriers. Cortés Pellicer et al. [18], utilized an integrated approach of Total Interpretive Structural Modeling (TISM) and Cross-Impact Matrix Multiplication Applied to Classification (MICMAC) to prioritize the most dominant barrier categories to the successful implementation of RLs activities in electric vehicles lithium-ion batteries EVs-LIBs. Data were gathered using a questionnaire survey, which was administered to various experts in EVs-LIBs manufacturing/recycling and EVs manufacturing companies. The findings revealed that these categories, market and social, and Policy and regulations are the two most influencing barriers to the implementation of EVs-LIBs RLs. Hsu et al. [28], utilized a framework that is composed of an extensive literature review, Delphi method, and fuzzy analytical hierarchy process to analyze and give a deeper insight on RL of the leather footwear industry in Bangladesh. Waqas et al. [22], deployed a two-stage methodology of Delphi Method and Structural Equation Modeling in identification and verification of RL implementation barriers. A primary set of barriers that were identified through literature review were utilized in the Delphi process to screen out irrelevant barriers. More so, a survey-based questionnaire was administered to supply chain and logistics employees in the manufacturing sector and to some of the government authorities. Respondent's responses were analyzed in the Statistical Package for the Social Science (SPSS) \& AMOS 21 software. The five most critical RL barriers that were identified are a lack of financial capacity, lack of expertise in RL, weak government policies on RL subjects, absence of community pressure, and inefficient technologies/knowledge networks. Rameezdeen et al. [29], utilized an exploratory approach to examine the critical barriers faced by South Australian construction organizations in implementing RL practices. Twelve RL barriers were identified in the research, and four of them were found to be significant. The significant barriers were the lack of regulatory policies, the cost of instituting the RL system, poor RL recognition in the construction supply chain, and the extra effort required.

Moktadir et al. [30], examined the barriers of reverse logistics where a classical analysis was performed using the footwear industry. The survey was conducted on large and medium-size electronic companies to identify the RL barriers. The identified barriers were categorized as, Management barrier, Organization barrier, Product barrier, Technological barrier, Infrastructural barrier, Financial barrier, Involvement and Support barrier and Legal barrier. Kiatcharoenpol \& Sirisawat [31], in their study, took into consideration the selection of possible barriers as well as factors likely to affect the performance of reverse logistics by taking into consideration the Thai Electronic Industry as a case study. The classical technique gave a good performance value. Panjehfouladgaran [32], focused his research on potential risk management evaluation framework for reverse logistics (RL) industrial and manufacturing systems by implementing failure mode, effect analysis and multi-criteria decision-making processes under stochastic conditions. The proposed solution's usability and effectiveness were ascertained through numerical experimentations. Waqas, et al. [22], developed a strategy that will promote RL adoption in the Pakistani manufacturing industry by modeling RL barriers using Integrated ISM and MICMAC approaches. Santosh [5], conducted a study on computer supply chain-based firms in Bangladesh to examine the contextual relationship and interactions among barriers to RL implementation. Interpretive structural modeling was used as the analytical tool, 
and the findings from the study spotted a lack of interest from top management as the most influential barrier for computer supply. Guarnieri et al. [15], used Interpretive Structural Modeling (ISM) to study the interactions among the identified barriers of RL in a car manufacturing company based in Indonesia. MICMAC analysis was further used to analyze the relationship between the driver power and dependence power of each of the barriers. Ali et al. [33], explored the barriers of RL in an Egyptian leading Pharmaceutical company using ISM. The key finding from the study highlights a lack of regulatory enforcement and lack of awareness of RL activities as the most driving barriers. Ravi and Shankar [34], conducted intensive research focused on ISM-based classical techniques or approaches for the analysis or interactions among variables of reverse logistics using automobile industries as a case study.

In the literature on Logistics, Supply Chains and Sustainability, it is observed that less attention is given to research focused on RL in developing countries [32,34-36]. Most of the prior RL research focused more on drivers and barriers in developed countries [34]. Thus, research on RL needs to be viewed from a more macro perspective and requires a wide range of applications [37]. Reverse logistics has become increasingly important as a profitable and sustainable business strategy [38-41]. From the general review, it is a clear indication that the application of RL is still new in developing countries. Most organizations in developing nations focus more on the rule of thumb methods of analysis, rather than the qualitative and quantitative techniques. Therefore, this research is focused on the analysis of possible barriers to successful RL implementation in the Nigerian industry. The study proposes to use an integrated MCDM methodology based on IF-DEMATEL and EDAS. Results obtained will be beneficial to the Government of Nigeria, stakeholders, manufacturing companies and the entire populace. This will greatly resolve environmental issues, particularly hazardous waste disposal and management, economic issues, social issues and problems associated with handling end-of-life materials.

Recent studies in the African context are highlighted in Table 1. From Table 1, it is clear that none among the few pieces of research conducted in Nigeria addressed holistically the factors that influence RL development and adaptability in the Nigerian manufacturing industry. This study responds to a call for a comprehensive study to explore the barriers and practices of RL in the Nigerian manufacturing context. In this study, RL implementation barriers were identified through an extensive literature review. The process of barrier identification involved searching journal titles, contributions, abstracts and keywords using specific search words as "Reverse logistics", "Barriers/challenges", "Supply chain management", "Manufacturing industry", "Nigeria". The identified RL barriers were validated further by experts in the Nigerian manufacturing sector. The 21 finalized barriers were then categorized into five (5) core dimensions as organizational, technological, institutional, product-related and supply chain as shown in Table 2.

Table 1. Recent studies on Reverse logistics in Africa.

\begin{tabular}{cllc}
\hline Author(s) & \multicolumn{1}{c}{ Study Aim } & \multicolumn{1}{c}{ Research Method } & Country \\
\hline$[42]$ & $\begin{array}{l}\text { To assess the barriers to reverse logistics in the plastic } \\
\text { manufacturing industry } \\
\text { To bring to notice the main internal and external drivers and } \\
\text { barriers of RL within major South African grocery retailers. } \\
\text { To examine reverse logistics challenges in the manufacturing } \\
\text { pharmaceutical companies in South Africa. }\end{array}$ & Qualitative & Qualitative study \\
{$[44]$} & $\begin{array}{l}\text { Performance evaluation of reverse logistics adoption in food } \\
\text { industries in Kenya. } \\
\text { Reverse logistics practices and their effect on competitiveness on } \\
\text { food manufacturing, Nairobi, Kenya. }\end{array}$ & Qualitative and quantitative & South Africa \\
{$[45]$} & Quantitative & Kenya \\
\hline
\end{tabular}


Table 1. Cont.

\begin{tabular}{|c|c|c|c|}
\hline Author(s) & Study Aim & Research Method & Country \\
\hline [47] & $\begin{array}{l}\text { To analyze and design an effective reverse logistic system for } \\
\text { plastic bottles in Dire Dawa city in Ethiopia. }\end{array}$ & Qualitative and quantitative. & Ethiopia \\
\hline [48] & $\begin{array}{l}\text { Performance evaluation of RL process in a bottling } \\
\text { company, Ethiopia }\end{array}$ & Qualitative & Ethiopia \\
\hline [49] & $\begin{array}{l}\text { Measuring the performance of reverse logistics system in pet } \\
\text { bottles recovery in Ethiopian city. }\end{array}$ & qualitative and quantitative & Ethiopia \\
\hline$[50]$ & $\begin{array}{l}\text { To explore reverse logistics activities' impacts on the management } \\
\text { of waste products in the Nigerian manufacturing companies. }\end{array}$ & Qualitative and quantitative. & Nigeria \\
\hline [51] & $\begin{array}{l}\text { To examine solid waste management with respect to beverage } \\
\text { containers of soft and alcoholic drinks. }\end{array}$ & Quantitative & Nigeria \\
\hline [52] & $\begin{array}{l}\text { Performance evaluation of RL in a cosmetics company in Abia } \\
\text { State, Nigeria. }\end{array}$ & Quantitative & Nigeria \\
\hline [53] & $\begin{array}{l}\text { To investigate factors for successful implementation of reverse } \\
\text { logistics (RL) in Ghana. }\end{array}$ & Qualitative and quantitative. & Ghana \\
\hline [54] & $\begin{array}{l}\text { Performance evaluation of RL in sachet water bottling company } \\
\text { in Ghana. }\end{array}$ & Qualitative and quantitative. & Ghana \\
\hline [55] & $\begin{array}{l}\text { Investigation on Reverse Supply Chain (RSC) practices and their } \\
\text { obstacles in Moroccan companies. }\end{array}$ & Qualitative & Morocco \\
\hline
\end{tabular}

Table 2. Finalized barriers to implementing reverse logistics.

\begin{tabular}{|c|c|c|}
\hline Dimensions & Sub-Criteria/Barriers & References \\
\hline & Insufficient top management commitment (OG1) & \multirow{3}{*}[42,55-59]{} \\
\hline \multirow{4}{*}{ Organizational (OG) } & Financial constraints (OG2) & \\
\hline & Poor strategic planning of reverse logistics policies (OG3) & \\
\hline & Poor organizational culture (OG4) & \multirow{6}{*}[22,25,41,42,60,61]{} \\
\hline & Inadequate performance measurement system (TC1) & \\
\hline \multirow[t]{4}{*}{ Technological (TC) } & $\begin{array}{l}\text { Lack of proper infrastructure and supporting technologies for reverse } \\
\text { logistics practices (TC2) }\end{array}$ & \\
\hline & Negative past experience with innovative technologies (TC3) & \\
\hline & Low technical expertise/competence of employees (TC4) & \\
\hline & Inadequate government policies and support (IN1) & \\
\hline \multirow{4}{*}{ Institutional (IN) } & Absence of public awareness on reverse logistics adaptation (IN2) & \multirow{4}{*}[12,34,49,55,56]{} \\
\hline & Market instability and uncertainty of customers' behavior (IN3) & \\
\hline & Low competitive pressure (IN4) & \\
\hline & Lack of corporate social responsibility (IN5) & \\
\hline \multirow{5}{*}{ Product related (PD) } & Low product quality (PD1) & \multirow{5}{*}[34,55,56,59,62,63]{} \\
\hline & Low traceability of product life cycle (PD2) & \\
\hline & Improper marketing strategies for recovered products (PD3) & \\
\hline & Risk of storing hazardous materials (PD4) & \\
\hline & $\begin{array}{l}\text { Insufficient knowledge of the expected values and pricing of returned } \\
\text { products (PD5) }\end{array}$ & \\
\hline \multirow{3}{*}{ Supply chain related (SC) } & Minimal collaboration among supply chain partners (SC1) & \multirow{3}{*}[42,49,64-69]{} \\
\hline & Geographical location of facilities not close to end-customers (SC2) & \\
\hline & Insufficient trust in third-party logistics (SC3) & \\
\hline
\end{tabular}

\subsection{Application of IF-DEMATEL and EDAS}

In this study, IF-DEMATEL and EDAS are integrated to effectively analyze the barriers to implementing reverse logistics in the Nigerian manufacturing sector. Moreover, most decision models consider system criteria to be independent but then this view is contrary to real-life situations that present criteria as dependent entities [28]. Consequently, decision models like DEMATEL and ANP have become popular as viable means to solve the problem of inter-dependencies of system criteria [23,28]. However, decision methods are selected based on the specific problem and set of system criteria and as such, there is presently no available evidence that a certain decision model is more superior to the 
other $[23,70]$. Hence, given our study problem, we have selected IF-DEMATEL due to its potential for overcoming the fuzziness that is inherent in decision environments and also its ability to indicate the hesitancy of the decision-makers. Additionally, past published studies are available in the extant literature on the successful application of DEMATEL and its intuitionistic version to solving problems in the supply chain domain [71-75]. On the other hand, the EDAS method is based on two specific measures namely PDA and NDA which signify the difference between each solution (option) and the average solution [76,77]. Likewise, past published studies laud the superior benefits of EDAS in the rating of alternatives with regards to certain system criteria in the supply chain domain [77-86]. Thus, due to the many statistical benefits of IF-DEMATEL and EDAS as evidenced by their successful application in the extant literature, it becomes essential that we propose a hybrid model based on IF-DEMATEL and EDAS in the current study. The hybrid model will be effective in determining the interdependencies between system criteria under uncertainty and also providing an accurate ranking of the alternatives.

\section{Proposed Methodology}

In this study, we have proposed an integrated methodology that comprises three stages namely identification and confirmation, IF-DEMATEL and EDAS. Within the first stage (i.e., identification and confirmation), the system criteria (barriers to implementing reverse logistics) are identified from the literature review and then finalized using the inputs of experts in the Nigerian manufacturing sector. In the second stage, the IF-DEMATEL technique is applied to compute the importance weights of the system criteria. Then, in the third and final stage, the EDAS technique is utilized to compute the appraisal scores of the criteria and determine their ranking. An illustration of the proposed research methodology is presented in Figure 1.

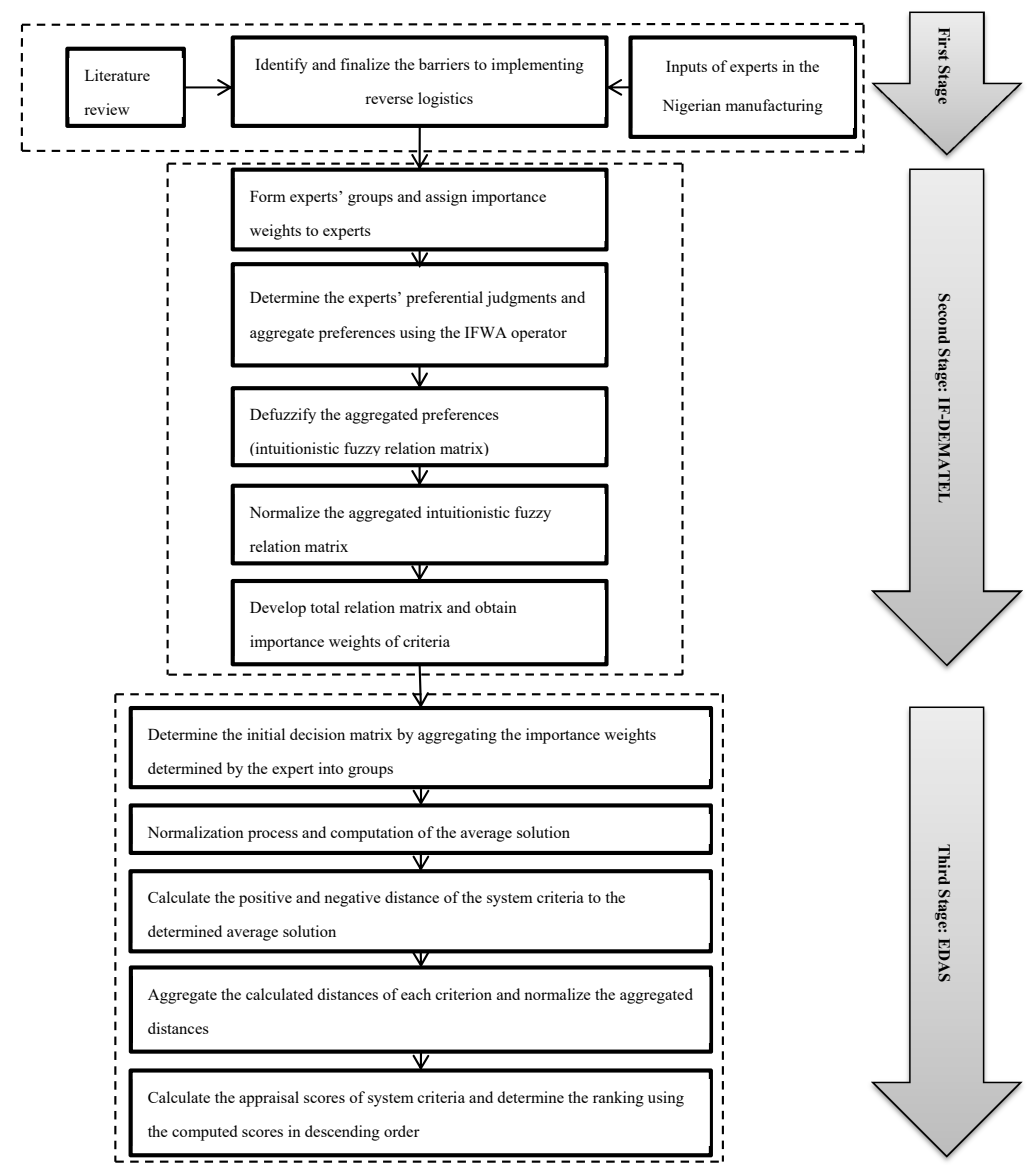

Figure 1. Proposed research methodology. 


\subsection{IF-DEMATEL}

Among the multi-criteria decision making (MCDM) methods, the DEMATEL is considered highly advantageous due to its strength in revealing the interactions/mutual relationships between system criteria and as such has seen wide and successful applications in extant literature $[68,69]$. The DEMATEL method is usually integrated with other approaches, such as the Grey Theory System (GTS), Interpretive Structural Modeling (ISM), Fuzzy theory and Two-Sided Matching (TSM) for ranking of barriers [70-73]. Nevertheless, the above-mentioned combinations with DEMATEL are not said to be void-free, since such combinations are incapable of accounting for the degree of experts' hesitancy, in addition to the vagueness and uncertainty in experts' judgment. Hence, in this paper, we have combined Intuitionistic Fuzzy Set (IFS) with DEMATEL to investigate the barriers to implementing reverse logistics in the Nigerian manufacturing sector. The IFS is highly efficient in considering the 'degree of agreement' and 'degree of disagreement' of experts and likewise, accounting for the uncertainty and vagueness in the decision-making environment [74]. In addition, the degree of hesitancy coupled with the non-membership and membership functions in the IFS theory can represent 'neutrality', 'support' and 'opposition' in complex environments [23-75]. Furthermore, the hesitancy degree in the IFS theory can aid in modeling the data vagueness while considering the uncertainty of experts judgments [74]. Consequently, the IFS theory compliments the DEMATEL, which is highly effective for illustrating the cause-and-effect relationships between the system criteria. The IF-DEMATEL steps include:

Step 1: Form expert groups and assign importance weights to experts

In this step, the experts are grouped based on their job roles and then prioritized by assigning importance weights via the linguistic scale presented in Table 3 and computed with Equation (1).

$$
\lambda_{y}=\frac{\left(\mu_{y}+\Pi_{y}\left(\frac{\mu_{y}}{\mu_{y}+w_{y}}\right)\right)}{\sum_{y=1}^{l}\left(\mu_{y}+\prod_{y}\left(\frac{\mu_{y}}{\mu_{y}+w_{k}}\right)\right)}
$$

where the sum of the importance weights assigned to the experts $=1$ as shown in Equation (8).

$$
\sum_{y=1}^{l} \lambda_{y}=1
$$

Table 3. IF-DEMATEL linguistic scale.

\begin{tabular}{cc}
\hline Linguistic Attributes & Intuitionistic Fuzzy Numbers \\
\hline Very high severity $(\mathrm{VH})$ & {$[0.90,0.10,0.00]$} \\
High severity $(\mathrm{H})$ & {$[0.75,0.20,0.05]$} \\
Medium severity $(\mathrm{M})$ & {$[0.50,0.45,0.05]$} \\
Low severity $(\mathrm{L})$ & {$[0.35,0.60,0.05]$} \\
No severity $(\mathrm{N})$ & {$[0.00,1.00,0.00]$} \\
\hline
\end{tabular}

Step 2: Determine the experts' preferential judgments and aggregate preferences using the IFWA operator.

Here, the intuitionistic judgments of the experts are obtained using the intuitionistic fuzzy weighted averaging operator (IFWA) presented in Equation (3). Afterward, 
the obtained intuitionistic judgments are aggregated to form the intuitionistic fuzzy relation matrix.

$$
\begin{aligned}
& p_{i j}=\operatorname{IFWA} A_{\lambda}\left(p_{i j}^{(1)}, p_{i j}^{(2)}, \ldots, p_{i j}^{(l)}\right)=\lambda_{1} p_{i j}^{(1)} \oplus \lambda_{2} p_{i j}^{(2)} \oplus \ldots \oplus \lambda_{l} p_{i j}^{(l)} \\
& =\left[1-\prod_{y=1}^{l}\left(1-\mu_{i j}^{(y)}\right)^{\lambda_{y}}, \prod_{y=1}^{l}\left(w_{i j}^{(y)}\right)^{\lambda_{y}}, \prod_{y=1}^{l}\left(1-\mu_{i j}^{(y)}\right)^{\lambda_{k}}-\prod_{y=1}^{l}\left(w_{i j}^{(y)}\right)^{\lambda_{y}}\right] \\
& p_{i j}=\left(\mu_{i j}, w_{i j}, \pi_{i j}\right) \mu_{i j}=\left(1-\prod_{y=1}^{l}\left(1-\mu_{i j}^{(y)}\right)^{\lambda_{y}}\right), w_{i j}=\left(\prod_{y=1}^{l}\left(w_{i j}^{(y)}\right)^{\lambda_{y}}\right), \\
& \pi_{i j}=\left(\prod_{y=1}^{l}\left(1-\mu_{i j}^{(y)}\right)^{\lambda_{y}}-\prod_{y=1}^{l}\left(w_{i j}^{(y)}\right)^{\lambda_{y}}\right)
\end{aligned}
$$

Step 3: Defuzzify the aggregated preferences (intuitionistic fuzzy relation matrix)

In this step, the aggregated intuitionistic preferences matrix $(X)$ of the experts are defuzzified using Equation (4) by assigning $\beta$ a value of 0.5 being that expert is neutral to risk in the case application $(4 ; 35)$.

$$
\begin{gathered}
\bar{p}=\mu_{i j}-w_{i j}+(2 \beta-1) \pi_{i j} \\
X=\left[\begin{array}{ccc}
0 & \ldots & \bar{p}_{1 n} \\
\vdots & \ddots & \vdots \\
\bar{p}_{n 1} & \ldots & 0
\end{array}\right]
\end{gathered}
$$

Step 4: Normalize the aggregated intuitionistic fuzzy relation matrix

Here, the aggregated intuitionistic fuzzy matrix $(X)$ is normalized using Equation (5).

$$
\lambda=\min \left[\frac{1}{\max 1 \leq i \leq n \sum_{j=1}^{n}\left|\overline{p_{i j}}\right|}, \frac{1}{\max 1 \leq j \leq n \sum_{i=1}^{n}\left|\overline{p_{i j}}\right|}\right] i, j \in\{1,2, \ldots, n\}
$$

where

$$
N=\lambda \times X
$$

Step 5: Develop total relation matrix and obtain importance weights of criteria

In this step, the total relation matrix is computed by using Equation (7). Where, $D$ is the sum of the horizontal values of the reverse logistics barriers while $P$ is the sum of the vertical values of the barriers. Then, the importance weights of the system criteria are computed using Equation (8).

$$
\begin{gathered}
R=N(1-N)^{-1} \\
v_{i}=\left\{\left(D_{i}+P_{i}\right)^{2}+\left(D_{i}-P_{i}\right)^{2}\right\}^{0.5} \\
V_{i}=\frac{v_{i}}{\sum_{i} v_{i}}
\end{gathered}
$$

The resulting importance weights obtained from the IF-DEMATEL computations are utilized to form the initial decision matrix in the EDAS method.

\subsection{EDAS}

The EDAS (Evaluation based on Distance from Average Solution) method is a new and efficient MCDM method that was proposed by Keshavarz et al. [78] and applied in the inventory classification problem. As expected, EDAS has been combined with several other MCDM methods to proffer solutions to different problems [77-80]. The EDAS method is notably effective to assess MCDM problems especially in case of conflicting criteria, such as in reverse logistics barriers and is based on two measures, i.e., positive and 
negative distances from the average solutions [74,76,81]. Indeed, EDAS is highly desirable due to its fewer and simple computational steps and also its computational efficiency in determining the ranking of system criteria based on appraisal scores [82-84]. Basically, the computational steps involved in the EDAS method are as follows:

Step 1: Develop initial decision matrix

In this step, the initial decision matrix is developed using the outputs from the IFDEMATEL to comprise of the alternatives (reverse logistics barriers in this case), set of criteria (the expert groups in this case) and score of alternatives with respect to criteria (importance weights of criteria determined by the expert groups in this case).

Step 2: Normalize the decision matrix and computation of the average solution

In this step, the initial decision matrix is normalized to result in dimensionless using Equation (10). Then, the average solution is calculated using Equation (11).

$$
\begin{gathered}
\alpha_{i z}^{N}=\frac{\alpha_{i z}}{\sum_{i=1}^{n} \alpha_{i z}} \\
d_{j}=\frac{\sum_{i=1}^{m} \alpha_{i z}^{N}}{n}
\end{gathered}
$$

Step 3: Computation of the positive and negative distance of the system criteria

In this step, based on the calculated average solution, the positive distance $\left(P D_{i j}\right)$ and negative distance $\left(N D_{i j}\right)$ of the system criteria are obtained using Equations (12) and (13) respectively.

$$
\begin{aligned}
P D_{i j} & =\frac{\max 0,\left(\alpha_{i z}^{N}-d_{j}\right)}{d_{j}} \\
N D_{i j} & =\frac{\max \left(0, d_{j}-\alpha_{i z}^{N}\right)}{d_{j}}
\end{aligned}
$$

Step 4: Aggregate and normalize the calculated distances

In this step, the computed distances from Step 3 are aggregated for each reverse logistics barrier and then normalized for the experts' groups using Equations (14) and (15).

$$
\begin{gathered}
A P_{i}=\sum_{j=1}^{n} P D_{i j} \\
A N_{i}=\sum_{j=1}^{n} N D_{i j}
\end{gathered}
$$

Thus, the normalization process for the aggregated values $\left(A P_{i}\right)$ and $\left(A N_{i}\right)$ will be carried out using Equations (16) and (17).

$$
\begin{gathered}
N A P_{i}=\frac{A P_{i}}{\max _{i} A P_{i}} \\
N A N_{i}=1-\frac{A N_{i}}{\max _{i} A N_{i}}
\end{gathered}
$$

Step 5: Compute the appraisal scores and subsequent ranking of system criteria

In this step, the appraisal scores are calculated using Equations (18), after which the system criteria (reverse logistics barriers in this case) are prioritized in the descending order of computed appraisal scores.

$$
A S_{i}=\frac{1}{2}\left(N A P_{i}+N A N_{i}\right)
$$




\section{An Application Case for the Proposed Methodology in the Nigerian Manufacturing Industry}

In this study, we have considered the Nigerian manufacturing sector particularly companies, which produce plastic products (e.g., cups and plates) and electrical fittings (PVC conduit fittings/cables and auto lamps), as application cases to show the severity of the reverse logistics and also reveal the efficiency and viability of the proposed methodology. Specifically, the study problem is focused on identifying and analyzing the severity of the barriers to implementing reverse logistics. The Nigerian manufacturing sector is laden with the responsibility to satisfy the requirements of customers in the country's huge teeming population and as such is in constant need to provide efficient reverse logistics alternatives in order to minimize waste and actualize sustainability benefits. Nevertheless, some barriers evidently stand in the way of the progress of reverse logistics in the Nigerian manufacturing sector. Moreover, since manufacturing firms in Nigeria just like in most emerging economies are bound to be faced with resource scarcity during implementing strategic initiatives, practical insights are needed on the most critical/severe barriers to overcome/minimize for the success of such ventures. Currently, in the existing manufacturing operational space in Nigeria, there is no comprehensive framework of the barriers to reverse logistics; instead, managers tend to channel resources on overcoming certain barriers based on a few interviews by company staff. Hence, the purpose of this study is to provide the managers and decision-makers, particularly in the Nigerian manufacturing sector, a comprehensive framework and evaluating methodology to analyze the barriers to implementing reverse logistics. The specific steps related to the proposed framework and methodology in the case study application, are presented in the following subsections.

\subsection{Expert Panel Formation Stage}

Expert's identification in every exploratory study plays a key role as they are relied on to provide valued responses [28,29]. In this study, experts were selected within the Southeastern and Southwestern part of Nigerian. The two regions are hubs for business excellence, and house approximately over thirty thousand small and medium scale (SME) enterprises. The criteria for the expert's selection were based on the expert's cognate years of experience within the supply chain tenets, willingness to participate, and readiness to participate. The eight selected experts were of varying age (30-60) and career length (5-20) years. The characteristics of the eight selected decision-making experts are given in Table 4 . The selected experts were told of the research purpose and the proposed methodology. The study survey was conducted in two phases. In the first phase, the experts were asked to revise the list of identified RL barriers from the literature that are relevant to the Nigerian manufacturing environment. The responses from this set of experts were used to design the questionnaire needed for the second phase. In the second phase, the experts were requested to give preferential judgments on the pairwise comparisons between the identified/revised RL barriers. The researchers also applied certain measures to ensure content validity and reduce response bias. For instance, we carried out a pilot study by requesting four Academic scholars in Business Administration and Cooperative economics \& management, with cognate experiences in global trade and supply chain, to validate the designed questionnaire. The resourceful feedbacks derived from the pilot study aided in the design of the questionnaire for the second phase of the survey.

\subsection{IF-DEMATEL Stage}

Within this stage of the proposed methodology, the IF-DEMATEL is applied to obtain the importance weights of the reverse logistics barriers with the aid of the inputs of experts in the Nigerian manufacturing sector. The considered experts consist of managers with more than ten years of experience in the middle and top management level of the manufacturing industry and specifically with job titles as operations managers, $R \& D$ managers, production managers and general managers. The experts' inputs were sourced using a designed questionnaire which comprises of two parts; in the first part, the demographic 
characteristics of the experts as shown in Table 4 are sourced while in the second part, the influence of the barriers on each other is ascertained using IF-DEMATEL linguistic scale (See Table 2).

The results of the IF-DEMATEL stage are presented as follows:

Step 1: The experts are organized into groups namely, operations managers, R\&D managers, production managers and general managers. Then, the expert groups were prioritized by applying importance weights to Equation (1). Accordingly, the importance weights of the groups are $0.3,0.26,0.22$ and 0.22 for $\lambda 1, \lambda 2, \lambda 3$ and $\lambda 4$ respectively.

Step 2: The experts' intuitionistic judgments are determined using the IF-DEMATEL evaluation scale (See Table 2) and afterward aggregated using the IFWA. The aggregated intuitionistic preferences on the barrier dimensions / categories and specific reverse logistics, for one of the expert groups, are presented in Tables 5 and 6 respectively.

Step 3: The aggregated intuitionistic fuzzy relation matrix for the expert groups is then defuzzified using Equation (4).

Step 4: The defuzzified intuitionistic fuzzy relation matrix of the respective barriers for the expert groups is normalized using Equations (5) and (6) as presented in Table 7.

Step 5: The total relation matrix is developed and then the importance weights as determined by the expert groups are computed as shown for one of the expert groups in Table 8 .

Table 4. Demographic characteristics of the study respondents and case firms.

\begin{tabular}{lc}
\hline \multicolumn{1}{c}{ Demographic Attribute } & Number of Respondents \\
\hline Age & 3 \\
$30-40$ & 4 \\
$41-50$ & 1 \\
$51-60$ & \\
Gender & 7 \\
Male & 1 \\
Female & \\
Highest educational qualification & 3 \\
Bachelor's degree & 5 \\
Postgraduate degree & \\
Years of experience & 6 \\
$5-10$ & 2 \\
$11-20$ & \\
Managerial position & 1 \\
R\&D manager & 4 \\
Production manager & \\
General manager & 3 \\
Operation manager & \\
Annual revenue (million naira) & 1 (Firm) \\
50-100 & \\
$110-200$ & 3 (Firms) \\
$210-1000$ & 1 (Firm) \\
Firm size (number of employees) & 7 (Firms) \\
30-100 & \\
$101-500$ &
\end{tabular}

Table 5. Aggregated intuitionistic fuzzy relation matrix of barrier categories for an expert group.

\begin{tabular}{llllll}
\hline \multicolumn{1}{c}{ Barrier Categories } & \multicolumn{1}{c}{ OG } & \multicolumn{1}{c}{ TC } & \multicolumn{1}{c}{ IN } & \multicolumn{1}{c}{ PC } & SC \\
\hline Organizational (OG) & $(0,1,0)$ & $(0.86,0.13,0.01)$ & $(0.35,0.6,0.05)$ & $(0.75,0.2,0.05)$ & $(0.68,0.29,0.03)$ \\
Technological (TC) & $(0.45,0.5,0.05)$ & $(0,1,0)$ & $(0.9,0.1,0)$ & $(0,1,0)$ & $(0.5,0.45,0.05)$ \\
Institutional (IN) & $(0.5,0.4,0.05)$ & $(0.9,0.1,0)$ & $(0,1,0)$ & $(0.35,0.6,0.05)$ & $(0.9,0.1,0)$ \\
Product-related (PD) & $(0.75,0.2,0.05)$ & $(0.68,0.29,0.03)$ & $(0.86,0.13,0.01)$ & $(0,1,0)$ & $(0.45,0.5,0.05)$ \\
Supply chain-related (SC) & $(0.75,0.2,0.05)$ & $(0.35,0.6,0.05)$ & $(0.86,0.13,0.01)$ & $(0.74,0.2,0.05)$ & $(0,1,0)$ \\
\hline
\end{tabular}


Table 6. Aggregated intuitionistic fuzzy relation matrix of specific barriers for an expert group.

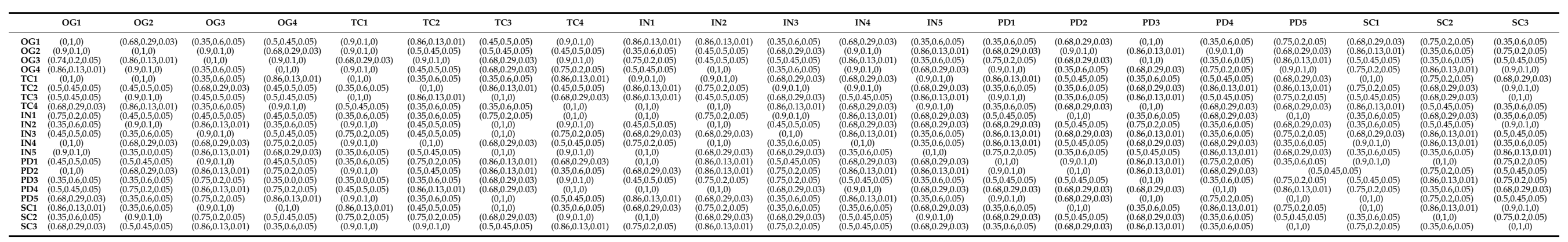

Table 7. Normalized relation matrix of specific barriers for an expert group.

\begin{tabular}{|c|c|c|c|c|c|c|c|c|c|c|c|c|c|c|c|c|c|c|c|c|c|}
\hline & OG1 & OG2 & OG3 & OG4 & TC1 & TC2 & TC3 & TC4 & IN1 & IN2 & IN3 & IN4 & IN5 & PD1 & PD2 & PD3 & PD4 & PD5 & SC1 & SC2 & SC3 \\
\hline OG1 & 0.053 & 0.39 & 0.061 & 0.038 & 0.0608 & -0.25 & 0.73 & 0.39 & 0.038 & 0.0418 & -0.25 & 0.061 & 0.0418 & 0.038 & -0.25 & -0.04 & 0.038 & -0.19 & -0.04 & -0.25 & 0.052 \\
\hline OG2 & 0.052 & -0.19 & 0.042 & -0.25 & 0.052 & 0.39 & 0.038 & -0.19 & 0.052 & -0.076 & 0.05 & 0.052 & -0.04 & 0.0418 & -0.19 & -0.19 & 0.052 & 0.052 & 0.0418 & -0.19 & -0.076 \\
\hline OG3 & 0.0608 & 0.39 & 0.052 & 0.39 & 0.038 & 0.042 & -0.25 & -0.04 & -0.25 & 0.73 & -0.19 & 0.038 & -0.19 & -0.04 & -0.04 & 0.061 & 0.052 & -0.04 & -0.04 & 0.042 & -0.04 \\
\hline OG4 & -0.04 & 0.0418 & 0.061 & -0.25 & 0.052 & 0.73 & 0.0418 & -0.25 & 0.038 & 0.0608 & -0.25 & 0.061 & -0.25 & -0.19 & 0.39 & -0.25 & -0.04 & 0.0608 & 0.038 & 0.73 & -0.19 \\
\hline TC1 & 0.0608 & 0.038 & -0.25 & 0.038 & -0.19 & 0.038 & 0.0608 & 0.39 & 0.0608 & 0.39 & 0.04 & -0.25 & 0.0608 & -0.04 & -0.19 & -0.08 & 0.061 & 0.038 & -0.25 & -0.04 & -0.076 \\
\hline TC2 & 0.73 & -0.19 & -0.076 & -0.25 & 0.39 & 0.042 & -0.25 & -0.25 & 0.0608 & 0.052 & -0.08 & -0.19 & -0.25 & 0.0608 & 0.73 & -0.19 & 0.052 & -0.19 & 0.038 & -0.19 & 0.053 \\
\hline TC3 & -0.25 & 0.038 & 0.042 & 0.0608 & -0.19 & -0.25 & 0.0418 & 0.052 & -0.19 & -0.076 & 0.05 & -0.08 & 0.0418 & 0.39 & 0.038 & 0.042 & 0.038 & -0.25 & -0.04 & -0.076 & 0.0418 \\
\hline TC4 & 0.038 & -0.04 & 0.038 & 0.39 & 0.052 & 0.042 & -0.04 & -0.19 & 0.73 & 0.052 & -0.19 & -0.25 & 0.038 & 0.0418 & 0.038 & -0.04 & -0.076 & 0.038 & -0.25 & 0.73 & -0.25 \\
\hline IN1 & -0.19 & 0.038 & -0.076 & 0.052 & 0.0418 & -0.04 & 0.038 & 0.73 & 0.0608 & -0.19 & 0.04 & 0.061 & -0.04 & 0.0608 & 0.042 & 0.061 & -0.19 & 0.0608 & 0.0608 & 0.39 & -0.19 \\
\hline IN2 & -0.25 & 0.0418 & 0.052 & 0.038 & 0.052 & 0.73 & 0.038 & 0.0608 & -0.25 & 0.73 & 0.06 & 0.39 & -0.25 & -0.04 & 0.052 & 0.061 & 0.73 & 0.052 & 0.053 & -0.04 & 0.0608 \\
\hline IN3 & 0.39 & 0.038 & -0.076 & 0.0608 & 0.038 & 0.042 & -0.25 & 0.052 & 0.73 & -0.25 & 0.06 & 0.73 & -0.19 & -0.25 & -0.08 & -0.04 & -0.25 & -0.04 & -0.076 & 0.73 & -0.04 \\
\hline IN4 & 0.038 & 0.0608 & -0.25 & 0.73 & 0.038 & -0.19 & -0.04 & -0.25 & -0.25 & -0.076 & -0.25 & -0.04 & -0.076 & 0.0608 & -0.25 & 0.39 & 0.061 & -0.25 & -0.04 & 0.39 & 0.0418 \\
\hline IN5 & -0.25 & -0.076 & -0.25 & 0.0418 & -0.25 & 0.052 & 0.0608 & 0.73 & -0.19 & 0.052 & -0.08 & 0.39 & -0.25 & -0.076 & 0.061 & -0.08 & -0.25 & 0.0608 & 0.0418 & -0.19 & -0.04 \\
\hline PD1 & -0.19 & 0.038 & 0.39 & 0.052 & -0.19 & 0.042 & -0.04 & -0.25 & -0.076 & 0.052 & 0.04 & -0.08 & 0.0608 & 0052 & 0.39 & 0.038 & -0.25 & 0.038 & 0.0608 & 0.39 & 0.038 \\
\hline PD2 & 0.038 & -0.25 & 0.042 & -0.25 & 0.038 & 0.73 & -0.19 & 0.052 & 0.39 & 0.73 & 0.04 & -0.25 & 0.0418 & -0.25 & -0.19 & -0.25 & -0.19 & -0.076 & -0.04 & -0.25 & 0.0418 \\
\hline PD3 & -0.19 & 0.052 & -0.25 & 0.038 & -0.19 & -0.25 & 0.038 & -0.25 & -0.19 & 0.0418 & 0.06 & 0.038 & 0.052 & 0.052 & 0.038 & -0.08 & 0.73 & 0.052 & -0.25 & -0.076 & 0.39 \\
\hline PD4 & -0.25 & 0.038 & 0.042 & 0.73 & -0.25 & 0.038 & -0.04 & 0.0608 & 0.052 & -0.19 & -0.08 & -0.04 & 0.0608 & -0.076 & 0.061 & -0.25 & 0.39 & -0.25 & -0.19 & 0.052 & -0.04 \\
\hline PD5 & 0.0418 & -0.19 & 0.061 & 0.0418 & 0.038 & -0.04 & 0.0608 & -0.076 & -0.25 & -0.076 & -0.25 & 0.7 & 0.038 & 0.0608 & 0.73 & -0 & 0.038 & 0.39 & -0.076 & 0.042 & 0.053 \\
\hline SC1 & -0.25 & 0.038 & -0.19 & 0.0418 & 0.052 & 0.038 & -0.04 & -0.25 & 0.39 & 0.0608 & -0.19 & -0.25 & 0.73 & -0.076 & 0.038 & 0.061 & 0.052 & 0.038 & -0.19 & 0.39 & 0.038 \\
\hline SC2 & 0.0608 & -0.19 & 0.39 & 0.038 & -0.25 & 0.042 & 0.73 & -0.076 & -0.25 & -0.076 & 0.39 & -0.08 & -0.25 & -0.04 & 0.39 & 0.042 & -0.04 & -0.25 & -0.19 & -0.25 & 0.0418 \\
\hline SC3 & 0.39 & -0.25 & -0.25 & 0.038 & 0.39 & -0.076 & 0.038 & 0.73 & 0.0608 & 0.73 & 0.04 & 0.038 & 0.0608 & -0.25 & -0.04 & 0.061 & 0.052 & 0.0608 & -0.04 & -0.04 & 0.0608 \\
\hline
\end{tabular}


Table 8. Total relation matrix of specific barriers for an expert group.

\begin{tabular}{|c|c|c|c|c|c|c|c|c|c|c|c|c|c|c|c|c|c|c|c|c|c|}
\hline & OG1 & OG2 & OG3 & OG4 & TC1 & TC2 & TC3 & TC4 & IN1 & IN2 & IN3 & IN4 & IN5 & PD1 & PD2 & PD3 & PD4 & PD5 & SC1 & SC2 & $\mathrm{SC} 3$ \\
\hline G1 & 528 & 059 & 856 & .004 & 0935 & 199 & .1203 & 311 & 0.08 & 0201 & 097 & 248 & 5513 & 0.103 & 3533 & 0.0323 & 0531 & .5333 & 0.511 & .0038 & 0.055 \\
\hline & & 252 & & & 826 & .0947 & 738 & .0709 & 026 & 0.182 & 717 & .114 & 662 & -0.1984 & 087 & 0.108 & 0.054 & 0087 & 0.1852 & 1343 & 0.0579 \\
\hline OG3 & -0.1512 & 0.0571 & 0.0031 & 465 & -0.04 & 0.137 & 0.027 & 056 & 0.005 & -0.0044 & 0.3954 & 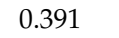 & 0.007 & 4417 & 0.1727 & -0.041 & 29 & 721 & 0.2144 & 0242 & 0.0487 \\
\hline OG4 & 0.137 & 198 & 0.0168 & .0406 & 0.0414 & 0.1005 & 0.115 & 0.038 & -0.0841 & -0.0074 & 0.0913 & 0.0726 & -0.118 & 0.1529 & 0.3954 & 0.377 & 0.3321 & 0.3953 & 0.107 & 0.1427 & -0.16 \\
\hline TC1 & -0.0805 & .0168 & 531 & 1583 & 01055 & 1445 & 0.0433 & 0479 & 00884 & 0.0933 & 0.3607 & 01572 & & 0385 & & 2326 & & 747 & 0.2217 & & .141 \\
\hline TC2 & 0.0884 & 0.0031 & 0.198 & -0.0928 & 0.0685 & 0.055 & -0.0527 & 0.0884 & -0.0209 & -0.1916 & 0.055 & 0.0703 & 769 & 888 & 0.4607 & 13 & 27 & .0571 & 954 & 31 & 0.0097 \\
\hline TC3 & -0.0114 & 0.0037 & 0.2059 & 1005 & 0.0775 & & & 00526 & 0.0732 & 0.0611 & 0.0595 & -0.0259 & & & & & & & & & 0.0265 \\
\hline TC4 & & 0.08 & & & 0 & > & $17-2>$ & & & 0.1427 & -00693 & 0208 & & & 00 & & & -0.0321 & & & 0.0775 \\
\hline IN1 & 0.0038 & 0.0723 & -0.2126 & -0.0523 & -0.018 & -0.1174 & -0.1452 & 0.018 & -0.0711 & 0.0242 & 0.2339 & 0.0298 & -0.029 & 0.3961 & -0.0693 & -0.21 & -0.1651 & -0.1543 & 0.2519 & 212 & -0.0585 \\
\hline IN3 & 0.032 & -0.0074 & -0.088 & 55 & & -0.0289 & -0.1005 & 0.0619 & -0.1408 & 0.0556 & 0.102 & 0.0131 & 0.0044 & 0.0366 & -0.0552 & 0.4225 & & -0.088 & -0.1137 & 0.1626 & -0.12 \\
\hline IN4 & -0.0114 & 0.0611 & 0.1938 & 0.1658 & 0.1007 & -0.0416 & 0.0503 & 0.0336 & 0.0275 & -0.2888 & -0.11 & 0.0734 & 0.0806 & -0.4515 & 0.0813 & -0.034 & 391 & 0.5 & 0.0039 & -0.0732 & -0.14 \\
\hline IN5 & & 0142 & & & -0076 & & & & -0.0314 & 0.3986 & 02464 & & & & & & & & & 0.0131 & 0.0365 \\
\hline PD1 & 0 & -0.2888 & 59 & 901 & 0.0247 & -0.15 & 0.0297 & & 02 & 0.0324 & -0.0813 & 0.1418 & 0.0 & 0.1 & 65 & & & -0 & 0.0655 & 0.125 & -0.118 \\
\hline PD2 & 0.0657 & 0.3986 & 0.5335 & 0.0686 & 0.1033 & -0.0097 & 0.0627 & - & 0 & -0.0657 & -0.0257 & -0.0527 & 0.0563 & 12 & 84 & 76 & & -0 & 0.0812 & -0.0192 & 0.036 \\
\hline PD3 & -0.1789 & 00224 & & & -0089 & 0265 & 00505 & (20018 & & & & & & & -0.1542 & & & & & 0.125 & 0.255 \\
\hline PD4 & -0.2487 & -0.0657 & 0.0304 & 0.0769 & 0.0815 & 0.0342 & -0.0004 & -0.0087 & 0.0383 & 0.0058 & 0.1959 & & & & -0.1835 & -0.15 & -0.11 & & 0.3618 & 0.1007 & 0.0581 \\
\hline PD5 & -0.1984 & -0.0197 & -0.088 & -0.0458 & -0.031 & -0.1005 & 0.0201 & 0.0206 & 0.2998 & -0.0853 & 0.0484 & 0.0317 & 0.1065 & 0.1982 & 0.1856 & 0.3411 & -0.0553 & 0.0 & 0.0279 & 0.0703 & -0.215 \\
\hline SC1 & & 00050 & & & & & & & & & & & & & & & & & & 0.0449 & \\
\hline SC2 & 0.0385 & -0.0853 & 0.0252 & 0.0513 & 0.0647 & 0.02 & -0.0611 & -0.0 & -0.0 & 0.00 & -0.1127 & -0.2 & -0 & & 0.0 & & 0.4 & -0 & -0.0765 & -0.038 & -0.013 \\
\hline $\mathrm{SC} 3$ & 0.198 & -0.012 & 0.0385 & 0.1065 & 0.218 & 0.0647 & 0.0206 & 0.2504 & -0.0303 & 0.0301 & 0.0731 & 0.2091 & 0.4996 & 0.2437 & 0.2093 & -0.212 & 0.1621 & 0.1181 & 0.0543 & -0.0433 & -0.1174 \\
\hline
\end{tabular}


The importance weights of the reverse logistics barriers categories and the specific barriers were then calculated for the expert groups. The importance weights of the barrier categories and specific barriers as obtained by one of the expert groups are presented in Tables 9 and 10 respectively.

Table 9. Importance weights of barrier categories as obtained by one of the expert groups.

\begin{tabular}{lccccc}
\hline \multicolumn{1}{c}{ Barrier Categories } & $\mathbf{D}$ & $\mathbf{P}$ & $\mathbf{D}+\mathbf{P}$ & $\mathbf{D}-\mathbf{P}$ & $\begin{array}{c}\text { Importance } \\
\text { Weights }\end{array}$ \\
\hline Organizational (OG) & 2.102 & 1.831 & 3.933 & 0.271 & 3.942 \\
Technological (TC) & 0.049 & 1.398 & 1.447 & -1.349 & 1.977 \\
Institutional (IN) & 3.725 & 2.833 & 6.558 & 0.892 & 6.618 \\
Product-related (PD) & 4.676 & 2.097 & 6.773 & 2.579 & 7.247 \\
Supply chain-related (SC) & 0.302 & 0.863 & 1.165 & -0.561 & 1.292 \\
\hline
\end{tabular}

Table 10. Importance weights of specific barriers as obtained by one of the expert groups.

\begin{tabular}{|c|c|c|c|c|c|}
\hline Reverse Logistics Barriers & $\mathbf{D}$ & $\mathbf{P}$ & $\mathbf{D}+\mathbf{P}$ & $\mathbf{D}-\mathbf{P}$ & $\begin{array}{l}\text { Importance } \\
\text { Weights }\end{array}$ \\
\hline Insufficient top management commitment (OG1) & 2.133 & 0.0055 & 2.1385 & 2.1275 & 3.016 \\
\hline Financial constraints (OG2) & 0.7778 & 0.9778 & 1.7556 & -0.2 & 1.865 \\
\hline Poor strategic planning of reverse logistics policies (OG3) & 1.5848 & 1.5038 & 3.0886 & 0.081 & 3.089 \\
\hline Poor organizational culture (OG4) & 1.9622 & 0.613 & 2.5752 & 1.3492 & 2.907 \\
\hline Inadequate performance measurement system (TC1) & 1.9769 & 0.8384 & 2.8153 & 1.1385 & 3.036 \\
\hline $\begin{array}{l}\text { Lack of proper infrastructure and supporting technologies for reverse } \\
\text { logistics practices (TC2) }\end{array}$ & 1.3882 & -0.0904 & 1.2978 & 1.2978 & 1.826 \\
\hline Negative past experience with innovative technologies (TC3) & 1.7642 & 0.219 & 1.9832 & 1.5452 & 2.526 \\
\hline Low technical expertise/competence of employees (TC4) & 0.7402 & 0.1885 & 0.9287 & 0.5517 & 1.079 \\
\hline Inadequate government policies and support (IN1) & -0.087 & 0.3718 & 0.2843 & -0.4593 & 0.5400 \\
\hline Absence of public awareness on reverse logistics adaptation (IN2) & 0.9511 & 0.4017 & 1.3528 & 0.5494 & 1.4600 \\
\hline Market instability and uncertainty of customers' behavior (IN3) & 0.9583 & 1.9846 & 2.9429 & -1.0263 & 3.116 \\
\hline Low competitive pressure (IN4) & 0.6234 & 0.9249 & 1.5483 & -0.3015 & 1.577 \\
\hline Lack of corporate social responsibility (IN5) & 0.6904 & 0.879 & 1.5694 & -0.1886 & 1.580 \\
\hline Low product quality (PD1) & 0.9166 & 2.3748 & 3.2914 & -1.4582 & 3.599 \\
\hline Low traceability of product life cycle (PD2) & 2.159 & 2.3767 & 4.5357 & -0.2177 & 1.450 \\
\hline Improper marketing strategies for recovered products (PD3) & 1.4169 & 1.2887 & 2.7056 & 0.1282 & 2.708 \\
\hline Risk of storing hazardous materials (PD4) & 0.3333 & 2.9955 & 3.3288 & -2.6622 & 4.262 \\
\hline $\begin{array}{l}\text { Insufficient knowledge of the expected values and pricing of returned } \\
\text { products (PD5) }\end{array}$ & 0.5431 & 2.4733 & 3.0164 & -1.9302 & 3.581 \\
\hline Minimal collaboration among supply chain partners (SC1) & 0.6581 & 2.8202 & 3.4783 & -2.1621 & 4.095 \\
\hline Geographical location of facilities not close to end-customers (SC2) & 0.196 & 1.1576 & 1.3536 & -0.9616 & 3.551 \\
\hline Insufficient trust in third party logistics (SC3) & 2.0811 & -0.5373 & 1.5438 & 2.6184 & 2.656 \\
\hline
\end{tabular}

\subsection{EDAS Application Stage}

After the expert groups in this study determined the importance weights of the reverse logistics barriers using the IF-DEMATEL steps, the EDAS method was then applied to prioritize the reverse logistics barriers. Then, the related EDAS steps were employed as follows:

Step 1: Develop initial decision matrix

The importance weights of the barrier categories and respective barriers, determined from the IF-DEMATEL were utilized as the initial decision matrix presented in Tables 11 and 12 respectively.

Step 2: Normalize decision matrix and compute average solution

The initial matrix presented in Table 8 was normalized, after which, the average solution was computed using Equations (10) and (11). 
Step 3: Computation of the positive and negative distances of the reverse logistics barriers to the average solution

The positive and negative distances of the reverse logistics barriers were determined using Equations (12) and (13).

Step 4: Aggregate and normalize calculated positive and negative distances of the reverse logistics barriers.

In this step, the computed positive and negative distances of the reverse logistics barriers were aggregated and normalized using Equations (14)-(17).

Step 5: Calculate appraisal scores and ranking of the system criteria

The appraisal scores of the barrier categories and specific reverse logistics barriers were computed using Equation (18). The ranking of the system criteria was done in descending order of the appraisal scores. The computed appraisal scores and ranking of the barrier categories and specific barriers are presented in Tables 13 and 14 respectively.

Table 11. EDAS initial matrix for reverse logistics barrier categories.

\begin{tabular}{lllll}
\hline \multicolumn{1}{c}{ Barrier Categories } & $\begin{array}{c}\text { Importance Weights } \\
\text { by Group 1 }\end{array}$ & $\begin{array}{c}\text { Importance Weights } \\
\text { by Group 2 }\end{array}$ & $\begin{array}{c}\text { Importance Weights } \\
\text { by Group 3 }\end{array}$ & $\begin{array}{c}\text { Importance Weights } \\
\text { by Group 4 }\end{array}$ \\
\hline Organizational (OG) & 3.942 & 5.453 & 3.124 & 1.676 \\
Technological (TC) & 1.977 & 2.183 & 1.561 & 2.833 \\
Institutional (IN) & 6.618 & 2.007 & 1.796 & 1.392 \\
Product-related (PD) & 7.247 & 1.783 & 1.923 & 1.524 \\
Supply chain-related (SC) & 1.292 & 1.537 & 0.392 & 2.119 \\
\hline
\end{tabular}

Table 12. EDAS initial matrix for specific reverse logistics barriers.

\begin{tabular}{|c|c|c|c|c|}
\hline Reverse Logistics Barriers & $\begin{array}{c}\text { Importance } \\
\text { Weights by } \\
\text { Group } 1\end{array}$ & $\begin{array}{c}\text { Importance } \\
\text { Weights by } \\
\text { Group } 2\end{array}$ & $\begin{array}{c}\text { Importance } \\
\text { Weights by } \\
\text { Group } 3\end{array}$ & $\begin{array}{c}\text { Importance } \\
\text { Weights by } \\
\text { Group } 4\end{array}$ \\
\hline Insufficient top management commitment (OG1) & 3.016 & 1.526 & 1.573 & 2.49 \\
\hline Financial constraints (OG2) & 1.865 & 2.4 & 2.087 & 2.013 \\
\hline Poor strategic planning of reverse logistics policies (OG3) & 3.089 & 1.006 & 2.532 & 3.544 \\
\hline Poor organizational culture (OG4) & 2.907 & 1.820 & 3.231 & 3.243 \\
\hline Inadequate performance measurement system (TC1) & 3.036 & 1.296 & 2.925 & 2.315 \\
\hline $\begin{array}{l}\text { Lack of proper infrastructure and supporting technologies for } \\
\text { reverse logistics practices (TC2) }\end{array}$ & 1.826 & 1.684 & 2.673 & 1.368 \\
\hline Negative past experience with innovative technologies (TC3) & 2.526 & 2.387 & 2.933 & 0.380 \\
\hline Low technical expertise/competence of employees (TC4) & 1.079 & 0.304 & 1.853 & 1.166 \\
\hline Inadequate government policies and support (IN1) & 0.540 & 0.210 & 1.081 & 0.391 \\
\hline Absence of public awareness on reverse logistics adaptation (IN2) & 1.460 & 1.301 & 2.842 & 2.193 \\
\hline Market instability and uncertainty of customers' behavior (IN3) & 3.116 & 1.053 & 3.660 & 1.172 \\
\hline Low competitive pressure (IN4) & 1.577 & 1.090 & 2.397 & 1.849 \\
\hline Lack of corporate social responsibility (IN5) & 1.580 & 1.035 & 2.463 & 2.496 \\
\hline Low product quality (PD1) & 3.599 & 2.125 & 3.445 & 2.862 \\
\hline Low traceability of product life cycle (PD2) & 1.450 & 1.043 & 4.572 & 1.104 \\
\hline Improper marketing strategies for recovered products (PD3) & 2.708 & 1.026 & 1.090 & 1.336 \\
\hline Risk of storing hazardous materials (PD4) & 4.262 & 2.087 & 2.087 & 2.176 \\
\hline $\begin{array}{l}\text { Insufficient knowledge of the expected values and pricing of } \\
\text { returned products (PD5) }\end{array}$ & 3.581 & 2.725 & 0.098 & 2.335 \\
\hline Minimal collaboration among supply chain partners (SC1) & 4.095 & 3.647 & 2.193 & 2.382 \\
\hline Geographical location of facilities not close to end-customers (SC2) & 3.551 & 4.725 & 1.832 & 1.772 \\
\hline Insufficient trust in third party logistics (SC3) & 2.656 & 3.674 & 2.383 & 0.614 \\
\hline
\end{tabular}


Table 13. Ranking of the barrier categories.

\begin{tabular}{|c|c|c|c|c|c|c|}
\hline Barrier Categories & $\begin{array}{c}\text { Positive } \\
\text { Solution }\left(P D_{i}\right)\end{array}$ & $\begin{array}{c}\text { Negative } \\
\text { Solution }\left(N D_{i}\right)\end{array}$ & $\begin{array}{c}\text { Aggregated } \\
\text { Positive } \\
\text { Solution }\left(A P_{i}\right) \\
\end{array}$ & $\begin{array}{c}\text { Aggregated } \\
\text { Negative } \\
\text { Solution }\left(A N_{i}\right)\end{array}$ & $\begin{array}{c}\text { Appraisal } \\
\text { Scores }\left(A S_{i}\right)\end{array}$ & Ranking \\
\hline Organizational & 0.431 & 0.875 & 0.907 & 0.586 & 0.5 & 3 \\
\hline Technological & 0.210 & 0.125 & 0.512 & 0.264 & 0.556 & 2 \\
\hline Institutional & 0.323 & 0.401 & 0.273 & 0.103 & 0.562 & 1 \\
\hline Product-related & 0.155 & 0.433 & 0.612 & 0.511 & 0.4 & 4 \\
\hline Supply chain-related & 0.691 & 0.205 & 0.532 & 0.561 & 0.314 & 5 \\
\hline
\end{tabular}

Table 14. Ranking of specific reverse logistics barriers.

\begin{tabular}{|c|c|c|c|c|c|c|}
\hline Reverse Logistics Barriers & $\begin{array}{l}\text { Positive } \\
\text { Solution } \\
\quad\left(P D_{i}\right)\end{array}$ & $\begin{array}{c}\text { Negative } \\
\text { Solution } \\
\left(N D_{i}\right)\end{array}$ & $\begin{array}{c}\text { Aggregated } \\
\text { Positive } \\
\text { Solution } \\
\left(A P_{i}\right)\end{array}$ & $\begin{array}{c}\text { Aggregated } \\
\text { Negative } \\
\text { Solution } \\
\left(A N_{i}\right)\end{array}$ & $\begin{array}{c}\text { Appraisal } \\
\text { Scores } \\
\left(A S_{i}\right)\end{array}$ & Ranking \\
\hline Insufficient top management commitment (OG1) & 0.631 & 0.081 & 0.980 & 0.876 & 0.552 & 6 \\
\hline Financial constraints (OG2) & 0.272 & 0.821 & 0.715 & 0.565 & 0.575 & 4 \\
\hline $\begin{array}{l}\text { Poor strategic planning of reverse logistics } \\
\text { policies (OG3) }\end{array}$ & 0.423 & 0.907 & 0.483 & 0.403 & 0.493 & 10 \\
\hline Poor organizational culture (OG4) & 0.203 & 0.646 & 0.364 & 0.000 & 0.54 & 7 \\
\hline $\begin{array}{l}\text { Inadequate performance measurement } \\
\text { system (TC1) }\end{array}$ & 0.961 & 0.593 & 0.660 & 0.753 & 0.453 & 12 \\
\hline $\begin{array}{l}\text { Lack of proper infrastructure and supporting } \\
\text { technologies for reverse logistics practices (TC2) }\end{array}$ & 0.917 & 0.628 & 0.230 & 0.633 & 0.298 & 19 \\
\hline $\begin{array}{l}\text { Negative past experience with innovative } \\
\text { technologies (TC3) }\end{array}$ & 0.318 & 0.818 & 0.383 & 0.713 & 0.335 & 17 \\
\hline $\begin{array}{l}\text { Low technical expertise/competence of } \\
\text { employees (TC4) }\end{array}$ & 0.132 & 0.339 & 0.890 & 0.561 & 0.664 & 3 \\
\hline Inadequate government policies and support (IN1) & 0.879 & 0.953 & 0.338 & 0.382 & 0.478 & 11 \\
\hline $\begin{array}{l}\text { Absence of public awareness on reverse logistics } \\
\text { adaptation (IN2) }\end{array}$ & 0.985 & 0.735 & 0.008 & 0.527 & 0.240 & 20 \\
\hline $\begin{array}{l}\text { Market instability and uncertainty of customers' } \\
\text { behavior (IN3) }\end{array}$ & 0.593 & 0.634 & 0.836 & 1.000 & 0.418 & 14 \\
\hline Low competitive pressure (IN4) & 0.459 & 0.237 & 0.136 & 0.523 & 0.306 & 18 \\
\hline Lack of corporate social responsibility (IN5) & 0.364 & 0.295 & 0.375 & 0.641 & 0.367 & 16 \\
\hline Low product quality (PD1) & 0.673 & 0.275 & 1.000 & 0.328 & 0.836 & 1 \\
\hline Low traceability of product life cycle (PD2) & 0.236 & 0.146 & 0.647 & 0.768 & 0.439 & 13 \\
\hline $\begin{array}{l}\text { Improper marketing strategies for recovered } \\
\text { products (PD3) }\end{array}$ & 0.726 & 0.668 & 0.652 & 0.539 & 0.556 & 5 \\
\hline Risk of storing hazardous materials (PD4) & 0.615 & 0.482 & 0.647 & 0.091 & 0.778 & 2 \\
\hline $\begin{array}{l}\text { Insufficient knowledge of the expected values and } \\
\text { pricing of returned products (PD5) }\end{array}$ & 0.781 & 0.121 & 0.463 & 0.432 & 0.515 & 9 \\
\hline $\begin{array}{l}\text { Minimal collaboration among supply chain } \\
\text { partners (SC1) }\end{array}$ & 0.126 & 0.208 & 0.328 & 0.593 & 0.203 & 21 \\
\hline $\begin{array}{l}\text { Geographical location of facilities not close to } \\
\text { end-customers (SC2) }\end{array}$ & 1.959 & 0.365 & 0.374 & 0.543 & 0.415 & 15 \\
\hline Insufficient trust in third party logistics (SC3) & 0.221 & 0.525 & 0.351 & 0.277 & 0.537 & 8 \\
\hline
\end{tabular}

\section{Discussion}

In this section, a detailed discussion of the ranking obtained for the investigated reverse logistics barriers is presented in addition to the theoretical and practical implications of the study.

\subsection{Discussion on the Ranking of the Reverse Logistics Barriers}

According to the results, the categorized barriers were ranked across each other and the institutional barrier was ranked first, followed by the technological barrier and then the organizational barrier, product-related barriers and lastly the supply-chain related barriers. The detailed comparisons of the specific barriers within the grouped categories are shown in Table 13 and indicate that the top specific barrier is likened to low product quality (PD1). The six top specific barriers are as follows; low product quality (PD1); risk 
of storing hazardous materials (PD4); Low technical expertise/competence of employees (TC4); financial constraints (OG2); improper marketing strategies for a recovered product (PD3) and insufficient top management commitment (OG1). These six (6) highest ranked among the investigated twenty-one RL barriers are considered as the most severe barriers for successful implementation of RL concept in the Nigerian manufacturing sector. The least-ranked severe barrier is supply chain-related; minimal collaboration among the supply chain partners (SC1). Within each of the categories, the ranking result has shown that some barriers are more severe than others. In the organizational category, financial constraint (OG2) is the highest-ranked and thus, the most severe barrier within this group. This is followed by insufficient top management commitment (OG1) and then poor organizational culture (OG4). In the same vein, looking at the technological domain, low technical expertise (TC4) is the highest-ranked. This is followed by an inadequate performance measurement system (TC1) and negative past experiences with innovative technologies. The least ranked in this category is the lack of proper infrastructure and supporting technologies for RL practices (TC2). Inadequate government policies and support (INI) is the most highly ranked barrier to RL implementation in the institutional barriers category. The second in this category is market instability and uncertainty of customer behavior (IN3). The third-ranked barrier in this domain is the lack of corporate social responsibility (IN5). This is followed by low competitive pressure (IN4), and lastly absence of public awareness on RL adaptation (IN2). Within the product-related domain, low product quality (PD1) is the most severe barrier that impedes successful RL implementation in Nigeria. The second-ranked barrier in this domain is the risk of storing hazardous materials (PD4). This is followed by improper marketing strategies for recovered products (PD3). The least ranked barrier within this category is the low traceability of product lifecycle (PD2). Under the domain of specific supply chain-related barriers, the highest-ranked RL barrier is insufficient trust in third-party logistics (SC3). The next ranked barrier is the geographical location of facilities not close to end-customers (SC2), and the least-ranked is a minimal collaboration among supply chain partners (SC1). In this study, ten barriers were selected as being more severe, and this selection was made based on the order of ranking starting from 1 to 10 . The ten selected severe barriers were found to be members of the three barrier domains: product-related, organizational and technological. These ten barriers are enlisted in descending order of severity starting with low product quality (PD1) down to the poor strategic planning of RL policies (OG3). However, the remnant barriers in the list are also relevant but can be seen as trivial barriers, thus the aforementioned key barriers are likely to have a more negative impact on the success of RL implementation in the Nigerian manufacturing sector.

\subsection{Solving Similar Problem with Existing Model or Findings}

The proposed model and the findings from this study can be implemented to solve a similar problem in other developing countries, allowing for a better understanding and identification of possible differences between the barriers in Nigeria and other countries to be investigated in terms of social, political, economic, and geographic settings. This will be extremely beneficial to policymakers and authorities in such countries. To achieve this, the top barriers identified in this study can be compared to the top barriers in other nations to serve as a reference or benchmark [87]. Replicating this type of constructed classical model, as it has been done in previous studies would aid to drive to a very speedy conclusion during the study. For instance, in [88] the authors developed a classical model and matched their findings to an existent case scenario in China. In another study [89], the author compared the result obtained in a study conducted in the USA to address a similar problem in Ghana. Furthermore, the author of [90] compared his finding with a study conducted in Hong Kong to solve a similar problem in Burkina Faso. With the established facts, it is evident that the model developed in this study can be replicated to address problems in other parts of the world. Future research could focus on expanding, 
comparing, improving and replicating the classical model used in this study, as well as comparing the outcome to those of other emerging and industrialized countries.

\subsection{Study Implications}

In this study, we have sought to respond to several research questions with RL implementations. In this chapter, we conclude by briefly foregrounding some of the study's implications for practice, and some of the directions for future research that stem from the project. This study is a wake-up call for more innovative discoveries on reuse alternatives for the abundant waste materials in our environment. Even with the wide acceptance of this subject among the "green" scholars and practitioners, huge waste is still generated in Nigerian manufacturing firms. Reasons for the uncontrollable level of waste in society need to be explored to explain why the population is finding it difficult to capture the value in the waste that abounds. It is clear from the literature search that none among the few pieces of research conducted in Nigeria addressed or holistically analyzed RL barriers in terms of their severity. Most of the research focused on performance evaluation (3) and exploration of RL practices [4]. None of the research even presented a framework to effectively handle the complexities that are inherent in the multi-criteria structure of the barrier analysis of RL.

Our main aim in this study was to address RL implementation bottlenecks in the Nigerian manufacturing sector. We have done so by presenting a synergetic application of Intuitionistic Fuzzy Decision Making Trial and Evaluation Laboratory (IF-DEMATEL) and Evaluation based on Distance to Average Solution (EDAS) in the analysis of the barriers to implementing RL in the Nigerian Manufacturing context. Although past published studies exist in the extant literature on the barriers to implementing RL, there is a dearth of research that provides evidence on such a topic in the Nigerian manufacturing context. Thus, it is paramount to provide research evidence in Nigeria since RL barriers are known to vary in terms of severity in different industrial contexts.

Accordingly, the second major practical contribution of the present research is that it provides much-needed firsthand information on the severity of the RL implementation barriers in Nigeria. Ten barriers were selected among the twenty-one (21) evaluated barriers as being more severe to successful RL implementation in the Nigerian manufacturing context. These specific barriers are constrained within the three broad barrier domains: product-related, organizational, and technological. This study will serve as a compass for decision-makers in the Nigerian manufacturing sector in familiarizing themselves with the severity of the RL barriers, to effectively redesign their systems. Lastly, our study responds to the call made by, among others [50] to explore various sections of RL processes to enhance sustainable business performance, and for further advancement and theorization of the subject in a more distinct perspective.

\section{Conclusions}

In general terms, RL is in the epicenter of the global goal of carbon neutrality and a circular economy. RL initiative is quite innovative, considering recent product designs that consider the end-of-life cycle (EOL) of the product. In Nigeria, plastic industries mark $85 \%$ of small-scale and medium industries (SME) with an approximate staff strength of 4 million, thus making them a big employer of labor in the society. This industrial sector is involved in the production of a wide variety of products for diverse sectors like domestic appliances, upholstery fittings, automobile fittings, etc. The primary input resources are ethane and propane, and the output materials are all non-biodegradables; meaning that the used product does not revert to a circular process without treatment. Nigeria's teeming population and relevance of this industry in society from both the social and economic perspective has invariably brought about an unquantifiable amount of plastic material littered all over the environment. In our judgment, these materials are in our landfills, gutters, and erosion dumpsites thus signifying poor material utilization, since most of the used products are potential input materials with multiple reuse alternatives. It is a truism 
that most of the industries have started introducing reprocessed materials composites in the production process, but conclusions from the environmental fact findings still attest to the non-significant utilization of these neglected materials. The COVID-19 pandemic has been a big lesson to everybody and is not limited to a particular or set of industries. The cost of input materials for production rose unprecedentedly due to a league of factors ranging from supply chain disruption; border restrictions; trade restrictions and sanctions, medical burden; reduced workforce, etc. The odd consequences of the recent pandemic on trade networks have highlighted the utmost importance of instituting an efficient RL system.

Consequently, this study is a pioneering effort on analyzing the severity of the barriers to implementing reverse logistics within the Nigerian manufacturing sector through the application of an integrated MCDM methodology based on IF-DEMATEL and EDAS. As such, the proposed decision methodology is capable of providing reliable and accurate analysis of the severity of the investigated barriers given the statistical benefits of due consideration of experts' judgment ambiguity and imprecision. Initially, we conducted an in-depth review of available published studies to identify the barriers to implementing reverse logistics and with the aid of experts in the Nigerian manufacturing industry, the identified barriers were finalized. Data for the study analysis were sourced from eight managers in the Nigerian manufacturing sector who were deemed knowledgeable to complete the survey due to their level of managerial experience so as to ensure survey result accuracy. The integrated methodology based on IF-DEMATEL-EDAS was applied for the analysis of the reverse logistics barriers and their subsequent prioritization in terms of severity. The study results indicate that low product quality, risk of storing hazardous material and low technical expertise are considered the highly prioritized barriers to the successful implementation of reverse logistics within the Nigerian manufacturing industry. This signifies the criticality/severity of the highly prioritized barriers and necessitates that the managers and practitioners in the Nigerian manufacturing sector develop effective mechanisms to overcome such barriers.

Clearly, RL management system is still a teething and unexplored strategy in Nigeria but can make part of our economic bail-out options to rightly cushion the effect of this pandemic scare. Many SMEs should tilt their creative attention to the economy of recycling and product reuse. Sustainable development goals can only be achieved in this part of the world starting with a wide exploration of efficient material reuse options that would mitigate our excesses to environmental health. One of the limitations of this study is likened to the limited number of experts used as respondents. Future research efforts could consider a larger number of respondents so as to provide a broader scope of the study and aid in the generalization of study results. Furthermore, the proposed research methodology in this study can be applied to explore barriers to RL implementation in other countries and industries. Additionally, the solution to the study problem can be proffered using other decision models that differ from the IF-DEMALEL-EDAS, such as AHP, TOPSIS, ANP, ISM and even systems dynamics models.

Author Contributions: Conceptualization, C.M.U.-D., I.J.O. and M.O.; Data curation, C.M.U.-D. and I.J.O.; Formal analysis, I.J.O.; Investigation, I.J.O.; Methodology, C.M.U.-D. and I.J.O.; Software, I.J.O.; Writing—original draft, C.M.U.-D., I.J.O. and M.O.; Writing—review \& editing, C.M.U.-D., I.J.O. and M.O. All authors have read and agreed to the published version of the manuscript.

Funding: This research received no external funding.

Institutional Review Board Statement: Not applicable.

Informed Consent Statement: Not applicable.

Data Availability Statement: The study did not report any data.

Conflicts of Interest: The authors declare no conflict of interest. 


\section{References}

1. Bernon, M.; Tjahjono, B.; Ripanti, E.F. Aligning retail reverse logistics practice with circular economy values: An exploratory framework. Prod. Plan. Control 2018, 29, 483-497. [CrossRef]

2. Swanson, D.; Goel, L.; Francisco, K.; Stock, J. An analysis of supply chain management research by topic. Supply Chain Manag. Int. J. 2018, 23, 100-116. [CrossRef]

3. Sehnem, S.; Vazquez-Brust, D.; Pereira, S.C.F.; Campos, L.M.S. Circular economy: Benefits, impacts and overlapping. Supply Chain Manag. Int. J. 2019, 24, 784-804. [CrossRef]

4. Cricelli, L.; Greco, M.; Grimaldi, M. An investigation on the effect of inter-organizational collaboration on reverse logistics. Int. J. Prod. Econ. 2021, 240, 108216. [CrossRef]

5. Santosh Kumar, S. Studies on Some Aspects of Implementation of Reverse Logistics in Indian Context. Ph.D. Thesis, Biju Patnaik Central Library, National Institute of Technology, Odisha, India, 2019.

6. Job, M.L.; Njihia, M.; Maalu, J.; Iraki, X.N. Reverse Logistics and Competitive Advantage: The Mediating Effect of Operational Performance among Manufacturing Firms in Kenya. Eur. Sci. J. 2020, 16, 217. [CrossRef]

7. Garrido-Hidalgo, C.; Ramirez, F.J.; Olivares, T.; Roda-Sanchez, L. The adoption of internet of things in a circular supply chain framework for the recovery of WEEE: The case of lithium-ion electric vehicle battery packs. Waste Manag. 2020, 103, 32-44. [CrossRef]

8. Brandão, R.; Edwards, D.J.; Hosseini, M.R.; Melo, A.C.S.; Macêdo, A.N. Reverse supply chain conceptual model for construction and demolition waste. J. Waste Manag. Res. 2016, 1-15.

9. Sangwan, K.S. Key activities, decision variables and performance indicators of reverse logistics. Procedia Cirp. 2017, 61, 257-262. [CrossRef]

10. Orji, I.J. Examining the barriers to organizational change for sustainability and the drivers of sustainable performance in the metal manufacturing industry. Resour. Conserv. Recycl. 2019, 140, 102-114. [CrossRef]

11. U-Dominic, C.; Orji, I.J.; Okwu, M.O.; Mbachu, V.; Ayomoh, M. The Impact of COVID-19 Pandemic on Sustainable Supplier Selection Process. In Advancing Industrial Engineering through Teaching; University of Ibadan: Ibadan, Nigeria, 2021; pp. 1-28. ISBN 978-078-515-9.

12. Chinda, T. Examination of Factors Influencing the Successful Implementation of Reverse Logistics in the Construction Industry: Pilot Study. Procedia Eng. 2017, 182, 99-105. [CrossRef]

13. Bukhari, M.A. Reverse Logistics Network Design in Circular Economy: Promoting Sustainable Collection and Reuse for PostConsumer Textile and Clothing. Ph.D. Thesis, Universidad Politecnica de Madrid, Madrid, Spain, 2018.

14. Agrawal, S.; Singh, R.K. Analyzing disposition decisions for sustainable reverse logistics: Triple bottom line approach. Resour. Conserv. Recycl. 2019, 150, 104448. [CrossRef]

15. Guarnieri, P.; Cerqueira-Streit, J.A.; Batista, L.C. Reverse logistics and the sectoral agreement of packaging industry in Brazil towards a transition to circular economy. Resour. Conserv. Recycl. 2020, 153, 104541. [CrossRef]

16. Kinobe, J.R.; Gebresenbet, G.; Niwagaba, C.B.; Vinneras, B. Reverse logistics system and recycling potential at a landfill: A case study from Kampala City. Waste Manag. 2015, 42, 82-92. [CrossRef]

17. Pramono, S.N.W.; Ulkhaq, M.M.; Aulia, Z. Analysing the barriers of reverse logistics implementation: A case study. IOP Conf. Ser. Mater. Sci. Eng. 2021, 1072, 012063. [CrossRef]

18. Cortés Pellicer, P.; Alarcón Valero, F. Identification of reverse logistics decision types from mathematical models. J. Ind. Eng. Manag. 2018, 11, 239-249. [CrossRef]

19. Dutta, P.; Talaulikar, S.; Xavier, V.; Kapoor, S. Fostering revers logistics in India by prominent barrier identification and strategy implementation to promote circular economy. J. Clean. Prod. 2021, 294, 126241. [CrossRef]

20. Prakash, C.; Barua, M.K. Integration of AHP-TOPSIS method for prioritizing the solutions of reverse logistics adoption to overcome its barriers under fuzzy environment. J. Manuf. Syst. 2015, 37, 599-615. [CrossRef]

21. Sirisawat, P.; Kiatcharoenpol, T. Fuzzy AHP-TOPSIS approaches to prioritizing solutions for revers logistics barriers. Comput. Ind. Eng. 2018, 117, 303-318. [CrossRef]

22. Waqas, M.; Qianli, D.; Ahmad, N.; Zhu, Y.; Nadeem, M. Modeling Reverse Logistics Barriers in Manufacturing Industry of Pakistan: An ISM and MICMAC Approach. J. Adv. Manuf. Syst. 2020, 19, 309-341. [CrossRef]

23. Kilic, H.S.; Demirci, A.E.; Delen, D. An integrated decision analysis methodology based on IF-DEMATEL and IF-ELECTRE for personnel selection. Decis. Support Syst. 2020, 137, 113360. [CrossRef]

24. Buyukozkan, G.; Gocer, F.; Karabulut, Y. A new group decision making approach with IF AHP and IF VIKOR for selecting hazardous waste carriers. Measurement 2019, 134, 66-82. [CrossRef]

25. Sari, D.P.; Ulkhaq, M.M.; Rinawati, D.I.; Rasyida, D.R. Barriers of Reverse Logistics Implementation: A Case Study in a Car Battery Industry in Indonesia. Int. J. Supply. Chain. Manag. 2018, 7, $53-67$.

26. Badenhorst, A. Management practices to mitigate barriers in reverse logistics. J. Contemp. Manag. 2017, 14, 595-623.

27. Vieira, B.O.; Guarnieri, P.; Nofal, R.; Nofal, B. Multi-Criteria Methods Applied in the Studies of Barriers Identified in the Implementation of Reverse Logistics of E-Waste: A Research Agenda. Logistics 2020, 4, 11. [CrossRef]

28. Hsu, C.-W.; Kuo, T.-C.; Chen, S.-H.; Hu, A.H. Using DEMATEL to develop a carbon management model of supplier selection in green supply chain management. J. Clean. Prod. 2013, 56, 164-172. [CrossRef] 
29. Rameezdeen, R.; Chileshe, N.; Hosseini, M.R.; Lehmann, S. A qualitative examination of major barriers in implementation of revers logistics within the South Australian construction sector. Int. J. Constr. Manag. 2016, 3, 1-12.

30. Moktadir, M.A.; Rahman, T.; Ali, S.M. Examining barriers to reverse logistics practices in the leather footwear industry. Ann. Oper. Res. 2020, 293, 715-746. [CrossRef]

31. Kiatcharoenpol, T.; Sirisawat, P. A Selection of Barrier Factors Affecting Reverse Logistics Performance of Thai Electronic Industry Int. J. Intell. Eng. Syst. 2020, 13, 117-126. [CrossRef]

32. Panjehfouladgaran, H.R. A Risk Management Evaluation Framework for Reverse Logistics Organisations Using Failure Mode and Effect Analysis and Multi-Criteria Decision Making. Ph.D. Thesis, Universiti Putra Malaysia, Selangor, Malaysia, 2016.

33. Ali, A.H.; Zalavadia, S.; Barakat, M.R.; Eid, A. The Role of Sustainability on Reverse Logistics for Returning and Recycling. Arch Bus. Res. 2018, 6, 12-33.

34. Ravi, V.; Shankar, R. An ISM-based approach analyzing interactions among variables of reverse logistics in automobile industries. J. Model. Manag. 2017, 12, 36-52. [CrossRef]

35. Orji, I.J.; Shaoxuan, L. A dynamic perspective on the key drivers of innovation- led lean approaches to achieve sustainability in manufacturing supply chains. Int. J. Prod. Econ. 2020, 219, 480-496. [CrossRef]

36. Govindan, K.; Agarwal, V.; Darbari, J.; Jha, P.C. An integrated decision making model for the selection of sustainable forward and reverse logistic providers. Ann. Oper. Res. 2019, 273, 607-650. [CrossRef]

37. Kusi-Sarpong, S.; Sarkis, J. Sustainable supply chains and emerging economies. Resour. Conserv. Recycl. 2019, 143, 238-243. [CrossRef]

38. Gupta, H.; Kusi-Sarpong, S.; Rezaei, J. Barriers and overcoming strategies to supply chain sustainability innovation. Resour. Conserv. Recycl. 2020. [CrossRef]

39. Ayvaz, B.; Gorener, A. Reverse logistics in the Electronics waste industry. In Waste Management: Concepts, Methodologies, Tools, and Applications; IGI Global: Hershey, PA, USA, 2020.

40. Kazemi, N.; Modak, N.M.; Govindan, K. A review of reverse logistics and closed loop supply chain management studies published in IJPR: A bibliometric and content analysis. Int. J. Prod. Res. 2019, 57, 4937-4960. [CrossRef]

41. Saeed, A.; Adnan, M. Critical success factors of reverse logistics in construction and pharmaceutical sector. Int. J. Sci. Eng. Res. $2019,10,12$.

42. Mwanza, B.G.; Mbohwa, C. Reverse Logistics Barriers: A Case of Plastic Manufacturing Industries in Zambia. In Proceedings of the IEEE International Conference on Industrial Engineering and Engineering Management (IEEM), Macao, China, 15-18 December 2019; pp. 1240-1244.

43. Meyer, A.; Niemann, W.; Mackenzie, J.; Lombaard, J. Drivers and barriers of reverse logistics practices: A study of large grocery retailers in South Africa. J. Transp. Supply Chain Manag. 2017, 11, a323. [CrossRef]

44. Makaleng, M.S. Reverse logistics challenges in manufacturing pharmaceutical companies: A study in the City of Tshwane South Africa. In Proceedings of the 12th International Business Conference, Mauritius, 23-26 September 2018; pp. $254-266$.

45. Bor, J. Reverse Logistics and Performance of Food Industries in Kenya. J. Logist. Manag. 2020, 9, $23-30$.

46. Anne, M.; Nicholas, L.; Gicuru, I.; Bula, O. Reverse Logistics Practices and Their Effect on Competitiveness of Food Manufacturing Firms in Kenya. Int. J. Econ. Financ. Manag. Sci. 2015, 3, 678-684. [CrossRef]

47. Girma. Reverse Logistic Network Design and Analysis for Plastic Bottles-A Case Study in Dire Dawa City. Master's Thesis, Addis Ababa University, Addis Ababa, Ethiopia, 2018; pp. 1-105.

48. Gupta, B. Relationship between Reverse Logistics Practices and Organizational Performance. Ph.D. Thesis, Addis Ababa University, Addis Ababa, Ethiopia, 2016.

49. Wondimu, S. Measuring Performance of Reverse Logistics System in Pet Bottles Recovery in Eabsco. Master's Thesis, Addis Ababa University, Addis Ababa, Ethiopia, 2016.

50. Amole, B.B.; Adebiyi, S.; Arogundade, K.K. Reverse Logistics and Management of Waste Products: The Nigerian Manufacturing Firms Experience. Rev. Innov. Compet. 2018, 4, 57-74. [CrossRef]

51. Mobolaji, D. The Reverse Logistics of Beverage Containers (A Case Study of Lagos, Nigeria). Master's Thesis, Aalto University, Espoo, Finland, 2017.

52. Ahaiwe, E.O.; Nwadigoha, E.E. Reverse logistics practices and sales growth of starline nigeria limited, abia state. Niger. J. Manag. Sci. 2021, 22, 1-20.

53. Amoah, A.; Abubakar, N.; Koomson, E. Investigating into factors accounting for the effective implementation of reverse logistics in Ghana. Int. J. Multidiscip. Develop. 2017, 4, 539-550.

54. Ebenezer, A.; Zhuo, S. Reverse Logistics and Performance of Bottled and Serchet Water Manufacturing Firms in Ghana: The Intervening Role of Competitive Advantage. IOSR J. Bus. Manag. 2019, 21, 34-39.

55. Elbaz, J.; Frei, G.; Laguir, I. Reverse supply chain practices in developing countries: The case of Morocco. J. Manuf. Technol. Manag. 2018, 29, 198-216. [CrossRef]

56. Bouzon, M.; Govindan, K.; Rodriguez, C.M.T. Evaluating barriers for reverse logistics implementation under a multiple stakeholders' perspective analysis using grey decision making approach. Resour. Conserv. Recycl. 2018, 128, 315-335. [CrossRef]

57. Bouzon, M.; Govindan, K.; Taboada, C.M.; Campos, L.M.S.S.; Rodriguez, C.M.T.; Campos, L.M.S.S. Identification and analysis of reverse logistics barriers using fuzzy Delphi method and AHP. Resour. Conserv. Recycl. 2016, 108, 182-197. [CrossRef] 
58. Kaviani, M.A.; Tavana, M.; Kumar, A.; Michnik, J.; Niknam, R.; De Campos, E.A.R. An integrated framework for evaluating the barriers to successful implementation of reverse logistics in the automotive industry. J. Clean. Prod. 2020, 27, 122714. [CrossRef]

59. Orji, I.J.; Kusi-Sarpong, S.; Gupta, H. The critical success factors of using social media for supply chain social sustainability in the freight logistics industry. Int. J. Prod. Res. 2020, 58, 1522-1539. [CrossRef]

60. Simoes, R.; Carvalho, C.; Felix, R.; Arantes, A. Survey of Reverse Logistics Practices-The Case of Portugal. In Proceedings of the 6th International Conference on Operations Research and Enterprise Systems, Porto, Portugal, 23-25 February 2017; pp. 393-400. [CrossRef]

61. Kusi-Sarpong, S.; Gupta, H.; Sarkis, J. A supply chain sustainability innovation framework and evaluation methodology. Int. J. Prod. Res. 2019, 57, 1990-2008. [CrossRef]

62. Mangla, S.K.; Govindan, K.; Luthra, S. Critical success factors for reverse logistics in Indian industries: A structural model. J. Clean. Prod. 2016, 15, 608-621. [CrossRef]

63. Herbert-Hansen, Z.N.L.; Larsen, S.; Nielsen, A.; Groth, A.; Gregersen, N.G.; Ghosh, A. Combining or Separating Forward and Reverse Logistics. Int. J. Logist. Manag. 2018, 29, 216-236. [CrossRef]

64. Nakiboglu, G. Determining Reverse Logistics Motivation Factors and Barriers: Multiple Criteria Decision Making Application on Pipe Manufacturing Company. In Eurasian Business Perspectives. Eurasian Studies in Business and Economics; Bilgin, M., Danis, H., Demir, E., Can, U., Eds.; Springer: Cham, Switzerland, 2019; Volume 10. [CrossRef]

65. Han, W.; Huang, Y.; Hughes, M.; Zhang, M. The trade-off between trust and distrust in supply chain collaboration. Ind. Mark. Manag. 2021, 98, 93-104.

66. Mahadevan, K. Collaboration in reverse: A conceptual framework for reverse logistics operations. Int. J. Prod. Perform. Manag. 2019, 68, 482-504. [CrossRef]

67. Paula, I.C.; Campos, E.A.R.; Pagani, R.N.; Guarnieri, P. Are collaboration and trust sources for innovation in the reverse logistics? Insights from a systematic literature review. Supply Chain Manag. Int. J. 2019, 25, 176-222. [CrossRef]

68. Rehman, S.A.; Zhang, Y.; Khan, S.S. Reverse logistics and challenges: Supply chain management of Automobile Industry. Adv. Appl. Sci. 2017, 2, 80-86. [CrossRef]

69. Schamne, A.N.; Nagalli, A. Reverse Logistics in the Construction Sector: A Literature Review. Electron. J. Geotech. Eng. 2016, 21, 691-702.

70. Gardas, B.B.; Raut, R.D.; Narkhede, B. Reducing the exploration and production of oil: Reverse logistics in the automobile service sector. Sustain. Prod. Consum. 2018, 16, 141-153. [CrossRef]

71. Prakash, C.; Barua, M.K.; Pandya, K.V. Barrier analysis for reverse logistics implementation in Indian electronics industry using fuzzy analytic hierarchy process. Procedia Soc. Behav. Sci. 2015, 189, 91-102. [CrossRef]

72. Farooque, M.; Jain, V.; Zhang, A.; Li, Z. Fuzzy DEMATEL analysis of barriers to Blockchain-based life cycle assessment in China. Comput. Ind. Eng. 2020, 147, 106684. [CrossRef]

73. Li, B.; Zhang, Y.; Xu, Z. The medical treatment service matching based on the probabilistic linguistic term sets with unknown attribute weights. Int. J. Fuzzy Syst. 2020, 22, 1487-1505. [CrossRef]

74. Rajesh, R.; Ravi, V. Modeling enablers of supply chain risk mitigation in electronic supply chains: A Grey-DEMATEL approach. Comput. Ind. Eng. 2015, 87, 126-139. [CrossRef]

75. Trivedi, A.; Jakhar, S.K.; Sinha, D. Analyzing barriers to inland waterways as a sustainable transportation mode in India: A DEMATEL-ISM based approach. J. Clean. Prod. 2021, 295, 126301. [CrossRef]

76. Alam, S.T.; Ahmed, S.; Ali, S.M.; Sarker, S.; Kabir, G. Challenges to COVID-19 vaccine supply chain: Implications for sustainable development goals. Int. J. Prod. Econ. 2021, 239, 108193. [CrossRef]

77. Ocampo, L.; Yamagishi, K. Modeling the lockdown relaxation of the Philippine government in response to the COVID-19 pandemic: An intuitionistic fuzzy DEMATEL analysis. Socio-Econ. Plan. Sci. 2021, 72, 100911. [CrossRef]

78. Keshavarz Ghorabaee, M.; Zavadskas, E.K.; Olfat, L.; Turskis, Z. Multi-criteria inventory classification using a new method of evaluation based on distance from average solution (EDAS). Informatica 2015, 26, 435-451. [CrossRef]

79. Abdel-Basset, M.; Gamal, A.; Chakrabortty, R.K.; Ryan, M. Development of a hybrid multi-criteria decision-making approach for sustainability evaluation of bioenergy production technologies: A case study. J. Clean. Prod. 2021, 290, 125805. [CrossRef]

80. Kahraman, C.; Keshavarz Ghorabee, M.; Zavadskas, E.K.; Cevik Onar, S.; Yazdani, M.; Oztaysi, B. Intuitionistic fuzzy EDAS method: An application to solid waste disposal site selection. J. Environ. Eng. Landsc. Manag. 2017, 25, 1-12. [CrossRef]

81. Ma, Y.; Zhang, L.; Lv, X.; Cai, Z. An Integrated Strategy for Cost Optimization of Reverse Logistics Network under Uncertain Environment. Int. J. Econ. Financ. Manag. Sci. 2017, 5, 24-33. [CrossRef]

82. Peng, X.; Dai, J.; Yuan, H. Interval-valued fuzzy soft decision making methods based on MABAC similarity measure and EDAS. Fundam. Inform. 2017, 152, 373-396.

83. Kundakci, N. An integrated method using MACBETH and EDAS methods for evaluating steam boiler alternative. J. Multi-Criteria Decis. Anal. 2019, 26, 27-34. [CrossRef]

84. Mishra, A.R.; Mardani, A.; Rani, P.; Zavadskas, E.K. A novel EDAS approach on intuitionistic fuzzy set for assessment of helath-care waste disposal technology using new parametric divergence measures. J. Clean. Prod. 2020, 272, 122807. [CrossRef]

85. Asante, D.; He, Z.; Adjei, N.O.; Asante, B. Exploring the barriers to renewable energy adoption utilizing MULTIMOORA-EDAS method. Energy Policy 2020, 142, 111479. [CrossRef] 
86. Hou, W.-H.; Wang, X.-K.; Zhang, H.-Y.; Wang, J.-Q.; Li, L. Safety risk assessment of metro construction under epistemic uncertainty: An integrated framework using creedal networks and the EDAS method. Appl. Soft Comput. 2021, 108, 107436. [CrossRef]

87. Gupta, H.; Barua, M.K. Identifying enablers of technological innovation for Indian MSMEs using best- worst multi- criteria decision making method. Technol. Forecast. Soc. Chang. 2016, 107, 69-79. [CrossRef]

88. Chan, A.P.; Lam, P.T.; Chan, D.W.; Cheung, E.; Ke, Y. Critical success factors for PPPs in infrastructure developments: Chinese perspective. J. Constr. Eng. Manag. 2010, 136, 484-494. [CrossRef]

89. Darko, A.; Chan, A.P.C. Strategies to promote green building technologies adoption in developing countries: The case of Ghana. Build. Environ. 2018, 130, 74-84. [CrossRef]

90. Bagaya, O.; Song, J. Empirical study of factors influencing schedule delays of public construction projects in Burkina Faso. J. Manag. Eng. 2016, 32, 05016014. [CrossRef] 